Original Research Article

\title{
Survey of vitamin D and 25-hydroxyvitamin D in traditional native Alaskan meats, fish, and oils
}

\author{
Katherine M. Phillips ${ }^{\mathrm{a}}$, Pamela R. Pehrsson ${ }^{\mathrm{b}, *}$, Kristine Y. Patterson ${ }^{\mathrm{b}}$ \\ ${ }^{\text {a } U n i t e d ~ S t a t e s ~ D e p a r t m e n t ~ o f ~ A g r i c u l t u r e, ~ A g r i c u l t u r a l ~ R e s e a r c h ~ S e r v i c e, ~ N u t r i e n t ~ D a t a ~ L a b o r a t o r y, ~ B e l t s v i l l e, ~ M D, ~ U S A ~}$ \\ b Biochemistry Department, Virginia Tech, Blacksburg, VA, USA
}

\section{A R T I C L E I N F O}

\section{Keywords:}

Cholecalciferol

25-Hydroxycholecalciferol

Blubber

Marine mammals

Indian

Eskimo

Food analysis

Food composition

Indigenous foods

Seal oil

\begin{abstract}
A B S T R A C T
Greater consumption of traditional foods has been associated with improved vitamin D status in Arctic and subArctic populations, including Alaskan Native Americans. However, lack of vitamin D food composition data impairs epidemiological studies on health outcomes, and development of specific dietary recommendations. Vitamin $\mathrm{D}$, including $25(\mathrm{OH}) \mathrm{D}_{3}$ was quantified in samples of native fish, fish eggs, meats (caribou, goose, whale, seal) and traditionally prepared whale and seal oil collected from Alaskan tribes. Vitamin $\mathrm{D}_{3}, 25(\mathrm{OH}) \mathrm{D}_{3}$, and vitamin $D_{2}$ were assayed in alkaline-saponified samples by UPLC-MS, after derivatization with 4-phenyl-1,2,4triazole-3,5-dione, with in-house control materials and/or NIST SRM ${ }^{\circledR}$ 1546a Meat Homogenate included in each analytical batch. All but the land animals and bearded seal meat contained $\geq 2 \mu \mathrm{g}$ vitamin $\mathrm{D}_{3} / 100 \mathrm{~g}$, with $>10 \mu \mathrm{g} / 100 \mathrm{~g}$ in steelhead trout; dried sheefish, whitefish, smelt; smoked/dried salmon; fermented sheefish eggs; whale and seal oils. Large between-sample differences in bearded seal oil suggested possible effects of season and/or maturity on vitamin $\mathrm{D}$ content. $25(\mathrm{OH}) \mathrm{D}_{3}$ was $>0.3 \mu \mathrm{g} / 100 \mathrm{~g}$ in many foods, notably smoked salmon, beluga whale skin/fat and oil and spotted seal (but not other seal) oil, with the highest levels in dried beluga whale meat, skin/fat, and oil (up to 1.2 ). Vitamin $D_{2}$ was $<0.2 \mu \mathrm{g} / 100 \mathrm{~g}$ in all foods.
\end{abstract}

\section{Introduction}

Vitamin D is an essential nutrient for bone health and has been increasingly recognized as a factor in immune system modulation, musculoskeletal health, cancer, and other aspects of health and disease (Pludowski et al., 2013). Vitamin $\mathrm{D}_{3}$ is readily formed in the epidermis with sun (ultraviolet light) exposure, from its precursor, 7-dehydrocholesterol (Wacker and Holick, 2015). However, many individuals and populations have suboptimal vitamin $\mathrm{D}$ levels, as measured by serum 25-hydroxyvitamin $\mathrm{D}_{3}\left[25(\mathrm{OH}) \mathrm{D}_{3}\right]$ concentration (Holick, 2005; Ross et al., 2011), due to insufficient sun exposure or dietary intake. Populations at higher latitudes are particularly susceptible to deficiency (Barake et al., 2010; Chen et al., 2007; Webb et al., 1988), and in these groups, dietary sources of vitamin $\mathrm{D}$ become more significant. Studies have found higher serum $25(\mathrm{OH}) \mathrm{D}_{3}$ in individuals than what would be predicted by ultraviolet light (UV) exposure and dietary intake determined by food intake surveys and food composition data, and part of the explanation might be underestimation of dietary intake due to a lack of reliable and complete data for vitamin D in foods, particularly for $25(\mathrm{OH}) \mathrm{D}_{3}$ (Roseland et al., 2016; Taylor et al., 2016). Since 25(OH) $D_{3}$ has a higher biological activity than $D_{3}$ and is not routinely measured in foods or included in food composition databases, it may be an overlooked component of vitamin D intake (Cashman et al., 2012; Norman, 2008; Ovesen et al., 2003).

Suboptimal vitamin D status has been documented in a variety of Arctic and sub-Arctic populations, including Alaskan and Canadian Northwest Native Americans (Frost and Hill, 2008; Lebrun et al., 1993; Sharma et al., 2011; Singleton et al., 2015; Weiler et al., 2007). There has been a trend toward westernization of the diet of Native populations (Ballew et al., 2006; Johnson et al., 2009; Murphy et al., 1995; Nobmann et al., 2005), although greater consumption of traditional foods in North American Arctic and sub-Arctic populations has been associated with better vitamin D status (Andersen et al., 2013; Bersamin et al., 2007; Luick et al., 2014; Mansuri et al., 2016; Mohatt et al., 2007; Ryman et al., 2015; Sheehy et al., 2014). "Traditional" foods are defined as those "composed of items from the local, natural environment that are culturally acceptable" (Kuhnlein and Receveur, 1996). However, a lack of food composition data for traditional Native foods impairs both epidemiological studies on vitamin D status and health and the development of specific dietary recommendations for increasing vitamin D intake in these populations (Johnson et al., 2009).

Research on the role of vitamin D intake and health requires reliable

\footnotetext{
* Corresponding author at: Biochemistry Department (0308), 304 Engel Hall, Virginia Tech, Blacksburg, VA 24061, USA.

E-mail addresses: kmpvpi@vt.edu (K.M. Phillips), pamela.pehrsson@ars.usda.gov (P.R. Pehrsson).
} 
food composition data, including sampling that is relevant to the population being studied (Ahuja et al., 2013). Food sampling for the USDA National Food and Nutrient Analysis Program (NFNAP) (Haytowitz et al., 2008; Haytowitz and Pehrsson, 2018) has provided analytical food composition data for the USDA National Nutrient Database for Standard Reference (SR) (USDA, 2016), including foods for the What We Eat In America (WWEA) National Health and Nutrition Examination Survey (NHANES) (U.S. Department of Agriculture, Food Surveys Research Group, 2017). Sampling is based on statistical models that account for market share and sources of variability in the food supply, to obtain representative population-wide average food composition data (Perry et al., 2002). However, these models cannot be translated to Native populations, since traditionally harvested and prepared foods must be obtained from remote locations, directly from the tribes who may not have excess to spare. Thus, efforts to develop robust vitamin D data for traditional foods need to be focused on those that are significant sources of the nutrient. There is a lack of information on vitamin $\mathrm{D}$ in these foods to serve as a basis to narrow the number of foods for further investigation.

In general, foods naturally rich in vitamin D include fish and fish oils, and some meats and organ tissues. However, the level can vary widely among specific foods in these groups, and the content can vary based on location of sampling (Roseland et al., 2018). While some fish are high in vitamin D (e.g., salmon, trout), many others contain negligible vitamin D (Mattila et al., 1995; Roseland et al., 2018; Schmid and Walther, 2013). Thus, it is reasonable to expect that some Native Alaskan fish and meats might be high in vitamin $\mathrm{D}$, including $25(\mathrm{OH})$ $D_{3}$. Kuhlein at al. (2006) reported on the vitamin $D_{3}$ content of several traditional native North American meats and fish sampled from Canadian tribes, but did not include $25(\mathrm{OH}) \mathrm{D}_{3}$. Foods which are potentially good sources of $25(\mathrm{OH}) \mathrm{D}_{3}$ include some fish and organ meats (Roseland et al., 2018), pork fat (Clausen et al., 2003), and eggs from vitamin D supplemented hens (Exler et al., 2010). Furthermore, the vitamin D content of a particular species of fish or mammal can be influenced by diet or environment (Liu et al., 2013; Mattila et al., 1997; Rao and Raghuramulu, 1996; Roseland et al., 2018). Processing prior to consumption also can influence vitamin D; variation has been observed based on removal of the skin from meats and fish is removed (Pierens and Fraser, 2015), sun drying (Barnkob et al., 2016), and differences in cooking methods (Jakobsen and Knuthsen, 2014; Mattila et al., 1999; Roseland et al., 2018). Specific environmental conditions and methods of preserving (e.g. smoking, drying), storing, and cooking foods likely vary among different indigenous populations, which have localized food supplies and often unique techniques for handling and preparation and that deserve consideration when evaluating dietary intake in specific populations.

An effort to obtain food composition data specifically for Alaskan and American Indian Native (AIAN) traditional foods was initiated by the United States Department of Agriculture (USDA) Agricultural Research Service (ARS) Nutrient Data Laboratory (NDL) (Beltsville, MD), with funding from the National Institutes of Health Office of Research on Minority Health (ORMH) and the Indian Health Service (IHS) (Rockville, MD). The main focus was to obtain food composition data for key nutrients, for inclusion in the American Indian/Alaskan Native database in SR, to support efforts on health studies of Native Americans (Amy and Pehrsson, 2003; Johnson et al., 2009; Pehrsson et al., 2005a, b; Perry et al., 2002). Meanwhile, efforts were being made in general to add data on vitamin D to SR (Holden et al., 2008), including studies on analytical methods and quality control (Byrdwell et al., 2008; Byrdwell, 2009; Phillips et al., 2008), vitamin D content of fish and shellfish (Byrdwell, 2009; Byrdwell et al., 2013), milk (Patterson et al., 2010), eggs (Exler et al., 2013), and mushrooms (Phillips et al., 2011). A key part of this work was validating methods for vitamin D and 25(OH)D. Until recently, methods for vitamin D were generally not standardized and often gave disparate results between laboratories using similar methods (Byrdwell et al., 2008; Phillips et al.,
2008). More recently, methodology for measurement of vitamin D and 25(OH)D by LC-MS has been validated (Byrdwell, 2009; Huang et al., 2009). The USDA Nutrient Data Laboratory (Beltsville, MD) has demonstrated that it is possible to obtain consistent results for vitamin $\mathrm{D}_{3}$ and $25(\mathrm{OH}) \mathrm{D}_{3}$ among laboratories (Roseland et al., 2016). Matrixspecific control materials and certified reference materials are, however, critical to include to account for the many factors that impact accuracy and precision of vitamin D quantification in different types of foods (Roseland et al., 2018).

The objective of this work was to measure vitamin $\mathrm{D}_{3}$ and $25(\mathrm{OH}) \mathrm{D}_{3}$ in samples of traditional meats and fish obtained from Native Alaskan tribes, to screen for foods that could be a rich dietary source of vitamin $\mathrm{D}$, as a basis for focusing more detailed food composition studies as well as to add to the dearth of published data for traditional foods, using validated analytical methodology and including traceable quality control materials.

\section{Materials and methods}

\subsection{Sample collection}

The foods sampled included raw, preserved (dried, frozen, fermented, canned, smoked) and prepared (boiled or baked) fish, land and marine mammals, and marine mammal oils. Samples were collected from Alaskan Native tribes, according to the sampling framework described previously (Perry et al., 2002), from the locations shown in Fig. 1. The foods sampled were selected based on published research, informal surveys and interviews with tribal council, elders, and members (e.g., at clinical setting), collaboration (e.g., food frequency questionnaires from other government or academic studies and focus groups. Handling of Alaskan native endangered species samples was authorized under permit 782-1694 from the National Marine Mammal Laboratory of the Alaska Fisheries Science Center of the National Oceanic and Atmospheric Agency (Seattle, WA). All food collection was approved by the councils of each tribe, and where presentations and supportive documents were required they were submitted to the tribe.

Samples were obtained within and among villages and tribes, from festivals or markets, homes, senior centers (food parties) and schools, as summarized in Table 1. Multiple samples of each food were obtained when possible, although the number of samples was necessarily limited by the availability of extra food for this study. Prepared foods (smoked, boiled, dried, etc.) had been processed by traditional methods, but details of these procedures were not always available. The food samples were, as much as possible, weighed on site (as the amount collected was often considered a common portion), frozen, and then packed on dry ice or blue ice packs and shipped via overnight express to the Food Analysis Laboratory Control Center (FALCC) in the Biochemistry Department at Virginia Tech (Blacksburg, VA). Upon receipt at the FALCC, samples were inspected to confirm integrity and then stored frozen at $<-15$ $\pm 5^{\circ} \mathrm{C}$ until prepared for analysis.

\subsection{Sample preparation}

Samples were thawed in the refrigerator $\left(4 \pm 2{ }^{\circ} \mathrm{C}\right)$ prior to homogenization (meats and fish overnight, fish eggs 4-6 h, and oils until completely liquefied). Canned fish samples were homogenized using a Robot Coupe industrial stainless steel food processor (RSI $6 \mathrm{~V}$ Blixer, Robot Coupe USA, Jackson, MS). Other fish, meat, and fish egg samples were homogenized in the same manner, except with the addition of liquid nitrogen to aid the homogenization process. Oils were thawed at $4 \pm 2{ }^{\circ} \mathrm{C}$ until liquefied, then stirred in a stainless steel bowl with a stainless steel spoon to homogenize. After homogenization, subsamples were dispensed in 15-30 g aliquots among 30-mL or $60-\mathrm{mL}$ glass jars with Teflon $^{\mathrm{TM}}$-lined lids (Qorpak ${ }^{\circledR}$, Bridgeville, PA; \#GLC07098 and GLC-08640, respectively). The jars were sealed under nitrogen, surrounded with aluminum foil, and stored at $<-55^{\circ} \mathrm{C}$ until 


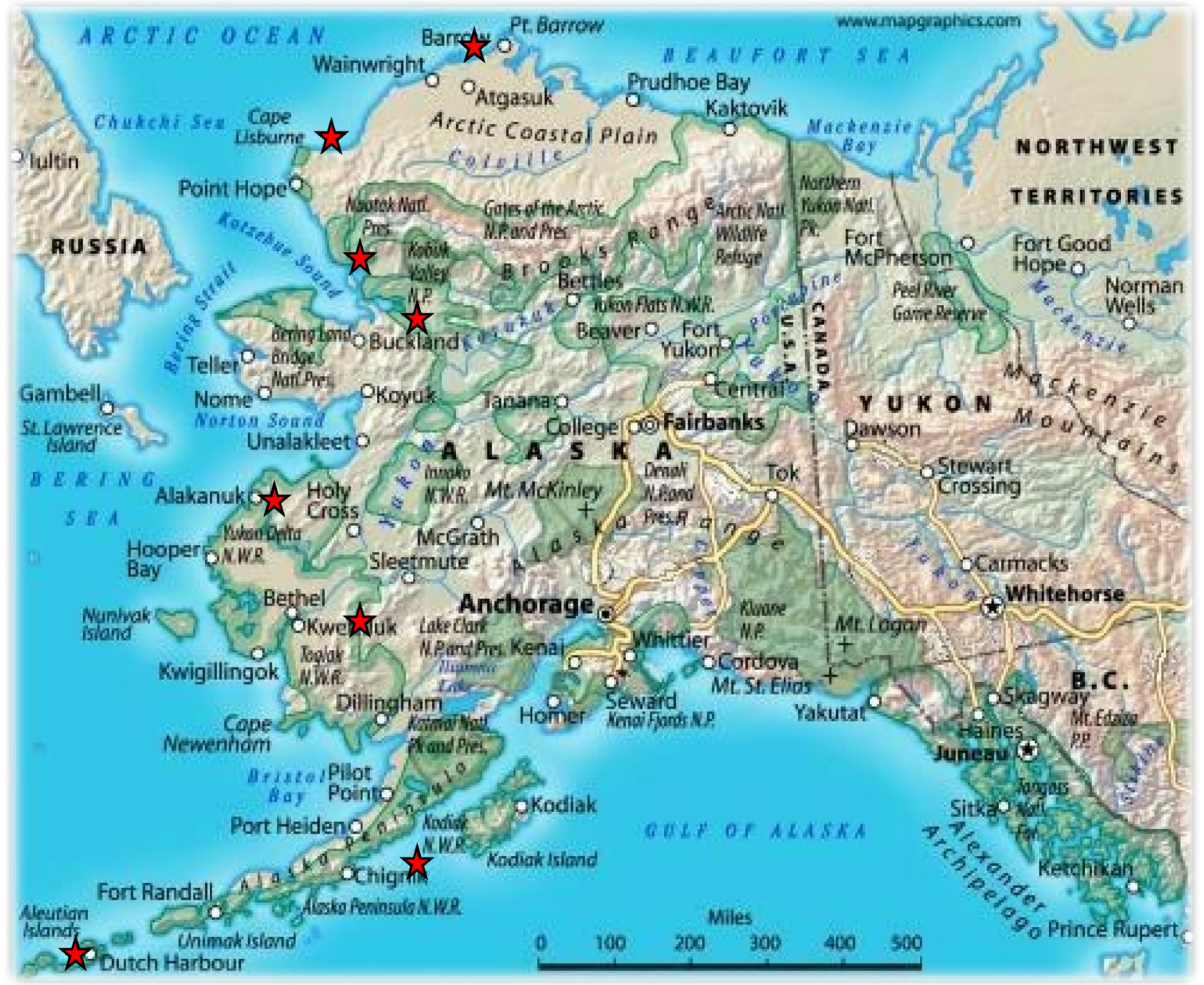

Fig. 1. Collection locations for native Alaskan food samples (Table 1) shown as stars (www.mappery.com/Alaska-Road-Map-3).

analyzed. Subsamples of each composite were batched with control and/or reference materials (Section 2.5) and shipped on dry ice via overnight express delivery to the laboratory, which confirmed receipt of the intact frozen samples, with dry ice remaining and stored them at $-70{ }^{\circ} \mathrm{C}$ until analyzed.

\subsection{Vitamin D analysis}

Vitamin $\mathrm{D}\left(\mathrm{D}_{3}, 25(\mathrm{OH}) \mathrm{D}_{3}\right.$, and $\left.\mathrm{D}_{2}\right)$ were analyzed by ultra-high performance liquid chromatography tandem mass spectrometry (UPLC-MS) at a commercial laboratory, which also participated in the inter-laboratory study on the analysis of vitamin D and 25(OH)D in food matrices (Roseland et al., 2016).

The analyses were conducted according to methodology reported by Huang et al. (2009). Briefly, a 2-10 g subsample of the homogenized food, with internal standard added $\left(\left[{ }^{2} \mathrm{H}_{3}\right)\right.$ cholecalciferol for vitamin $\mathrm{D}_{3}$, $\left[{ }^{2} \mathrm{H}_{3}\right] 25$-hydroxycholecalciferol for $25(\mathrm{OH}) \mathrm{D}_{3}$, and $\left[{ }^{2} \mathrm{H}_{3}\right]$ ergocalciferol for vitamin $\mathrm{D}_{2}$ ) (> 95\%; ISO Sciences, Ambler, PA, USA), was subjected to overnight alkaline saponification in alcoholic $\mathrm{KOH}$, under nitrogen and with $2 \%$ pyrogallic acid added. Non-saponifiables were extracted with ether/hexane (20:80 v/v/), dried, and re-dissolved in $70 \%$ aqueous acetonitrile, and derivatized with 4-phenyl-1,2,4-triazole-3,5dione. LC-MS analysis was performed with a Shimadzu (Columbia, MD, USA) UPLC with model LC30AD pump and SIL30AC injector coupled with an AB Sciex (Redwood City, CA, USA) API4000 triple quadrupole tandem mass spectrometer. A $100 \mathrm{~mm} \times 2.1 \mathrm{~mm}, 1.9 \mu \mathrm{m}$ C18 polar end-capped column [Hypersil GOLD ${ }^{\mathrm{TM}} \mathrm{aQ}$ (Thermo Scientific, Waltham, MA, USA)] was used, with $10 \mu \mathrm{L}$ injection volume and a mobile phase A of $0.1 \%$ formic acid $/ 20 \%$ methanol in ultra-purified water and mobile phase $\mathrm{B}$ of $1 \%$ formic acid in methanol, with the following gradient: $0-3.00 \mathrm{~min}, 5 \% \mathrm{~A} / 95 \% \mathrm{~B}$ at $0.25 \mathrm{~mL} / \mathrm{min} ; 3.00-5.20 \mathrm{~min}, 100 \% \mathrm{~B}$ at $0.25 \mathrm{~mL} / \mathrm{min} ; 5.20-5.21 \mathrm{~min}, 100 \% \mathrm{~B}$ at $0.25 \mathrm{~mL} / \mathrm{min} ; 5.21-9.00 \mathrm{~min}$, $100 \% \mathrm{~B}$ at $0.50 \mathrm{~mL} / \mathrm{min} ; 9.10-9.21 \mathrm{~min}, 5 \% \mathrm{~A} / 95 \% \mathrm{~B}$ at $0.50 \mathrm{~mL} / \mathrm{min}$; 9.21-10.0 $\mathrm{min}, 5 \% \mathrm{~A} / 95 \% \mathrm{~B}$ at $0.25 \mathrm{~mL} / \mathrm{min}$.

\subsection{Moisture and total fat analyses}

Moisture (AOAC, 2005a) and total fat (AOAC, 2005b) were also measured at the laboratory, along with control materials, to provide relevant proximate composition data.

\subsection{Quality control}

Samples of a Pork/Egg control material ("Pork/Egg CC, a mixture of bratwurst sausage and cooked egg yolks), and/or NIST SRM ${ }^{\circledR} 1546 \mathrm{a}$ Meat Homogenate [National Institute of Standards and Technology (NIST), Gaithersburg, MD] that were part of the inter-laboratory study (Roseland et al., 2016), and/or an in-house Salmon control material ("Salmon D CC", canned salmon) previously reported (Phillips et al., 2008) were analyzed with each batch of samples. Some of the Native 


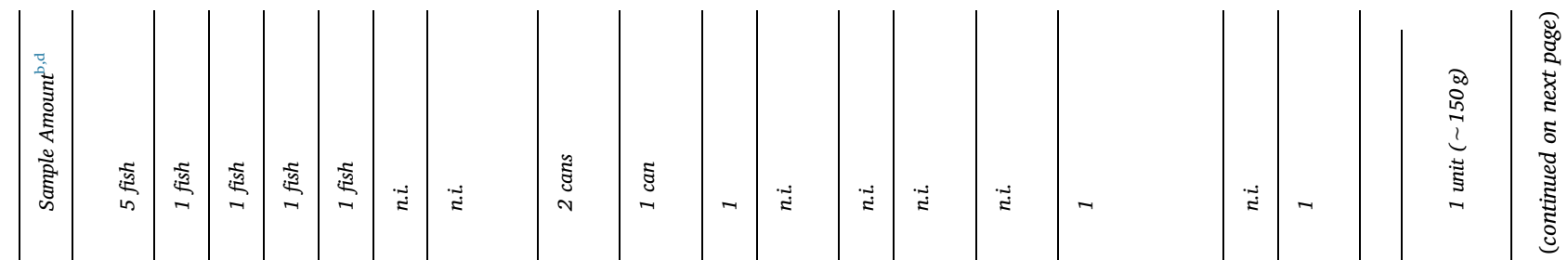

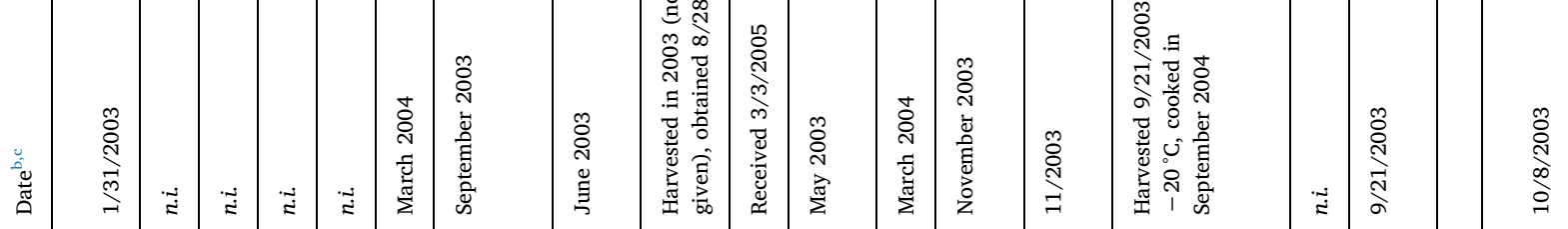

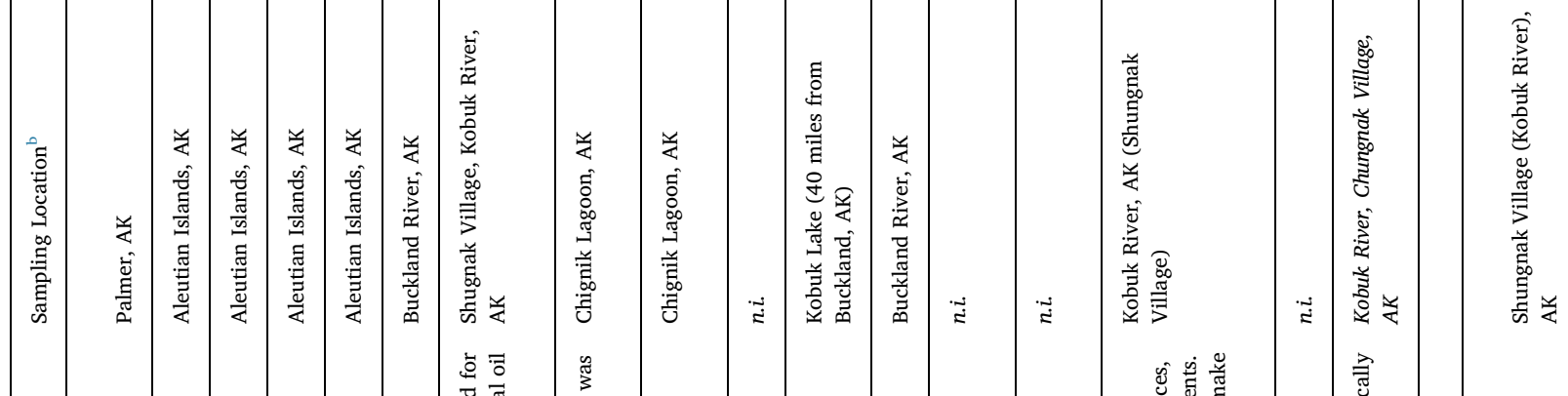

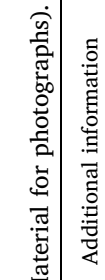

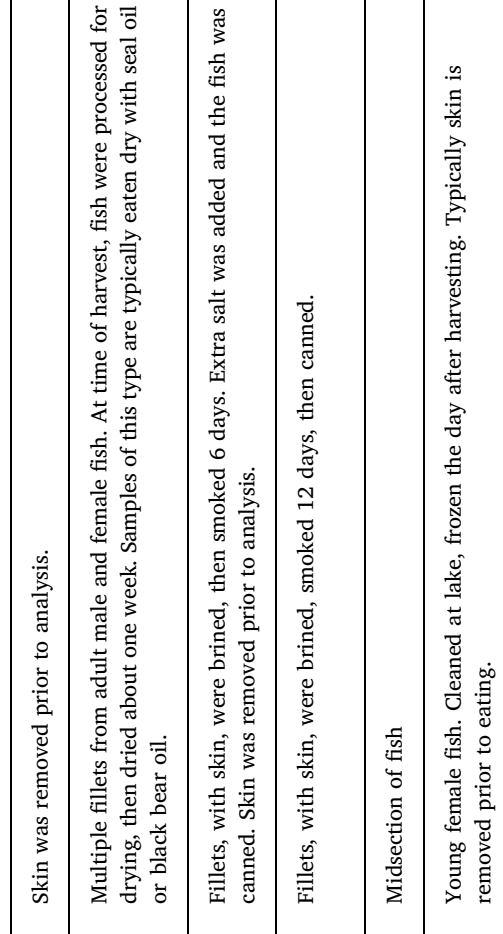

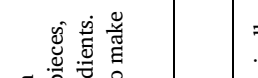

E

燰

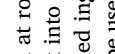

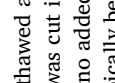

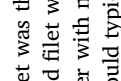

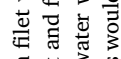

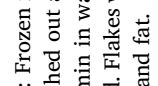

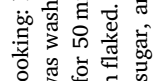

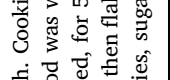

局 :

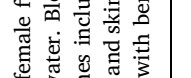

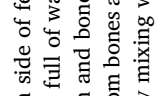

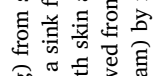

票品专产

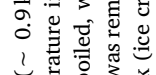

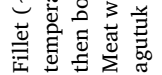



|

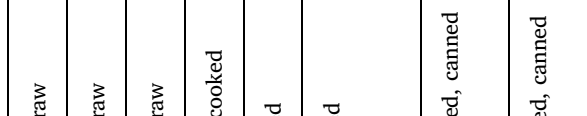

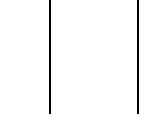

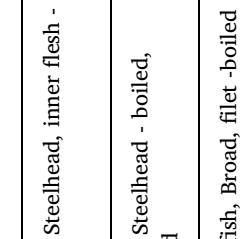

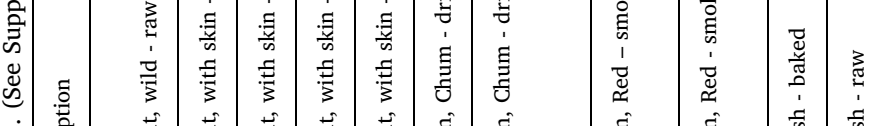

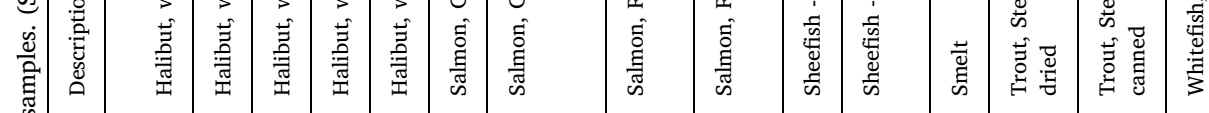

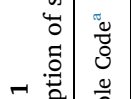

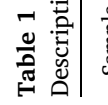

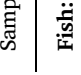
ำ

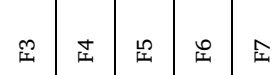

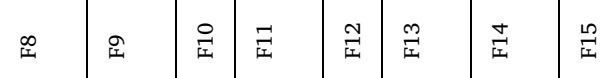

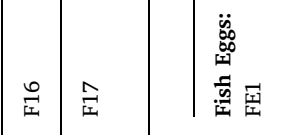




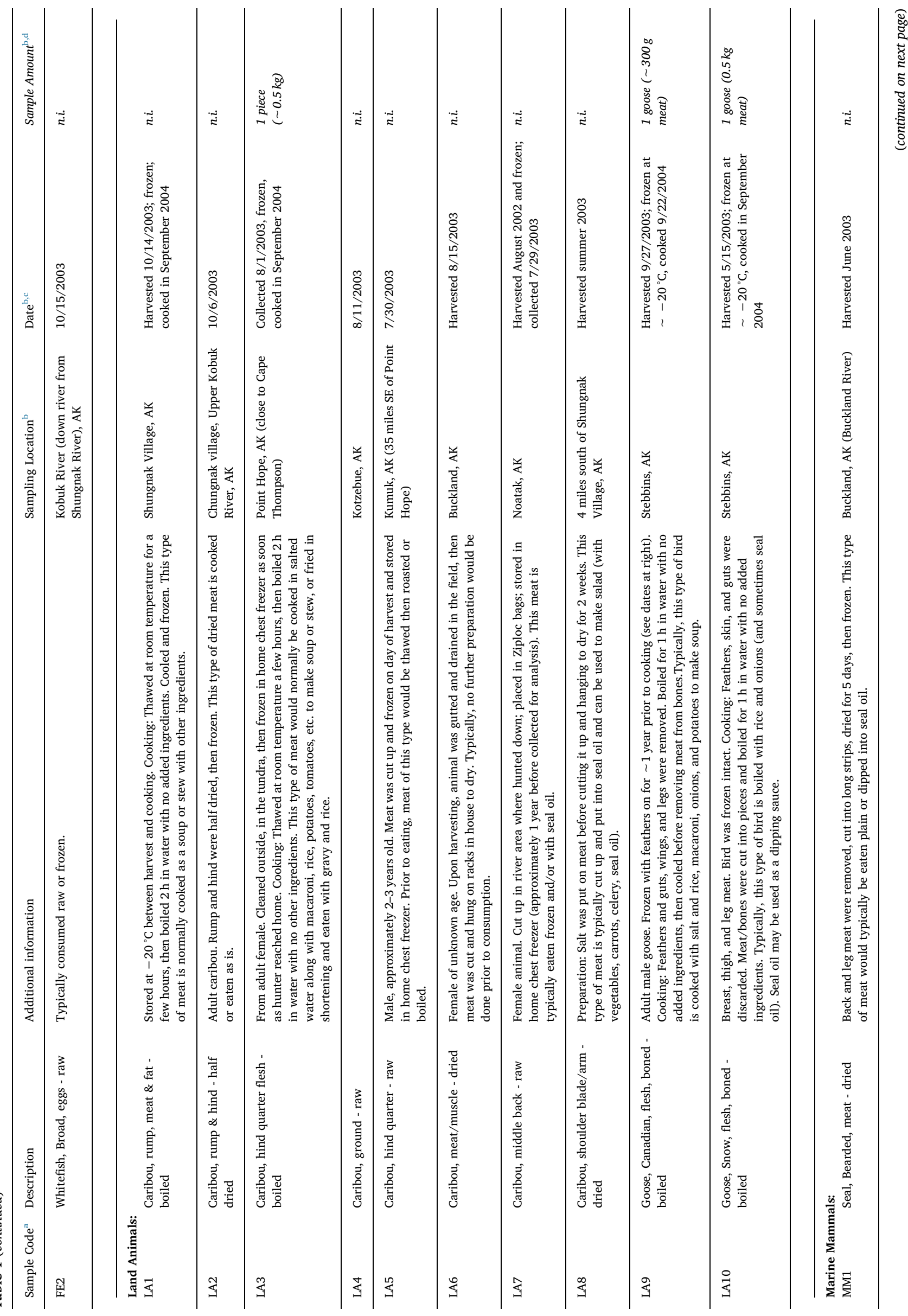




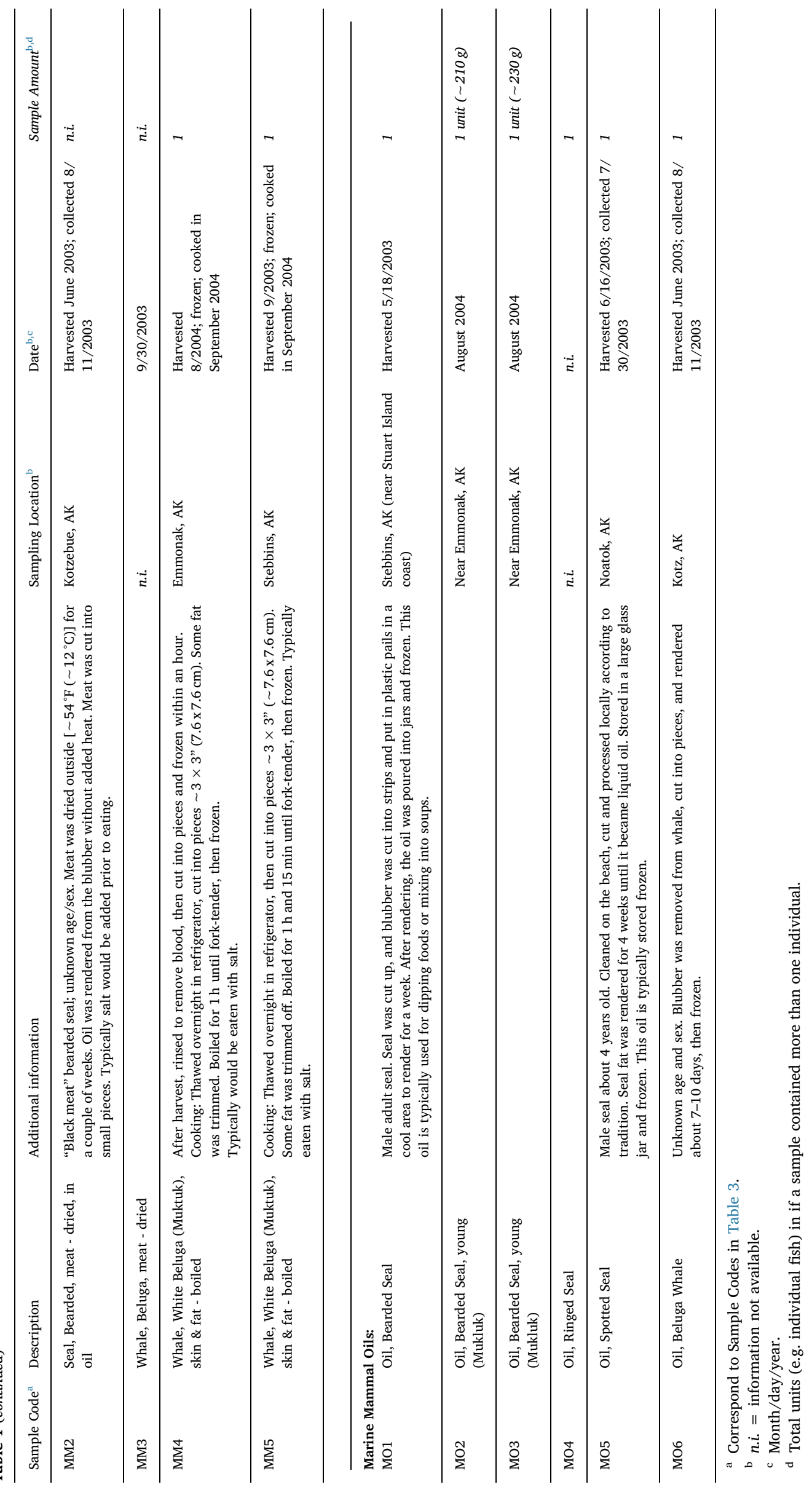


Alaskan samples were analyzed in replicate, in independent analytical runs as a measure of day-to-day precision. Precision was estimated by percent relative standard deviations (RSD) for the samples assayed in replicate and for the control materials assayed over multiple runs. Acceptability of the RSD in each case was evaluated using the Horwitz ratio (HorRat), the assayed RSD/expected RSD, where the expected $\mathrm{RSD}$ was calculated as the assayed mean $(\mu \mathrm{g} / 100 \mathrm{~g}) /(100 / 1,000,000)$ $\wedge^{-0.1505}$ (Horwitz and Albert, 2006).

Accuracy was validated by results for three commercially available relevant food matrix reference materials assayed in a previous interlaboratory study on quantitation of vitamin D and 25(OH)D (Roseland et al., 2016): NIST SRM ${ }^{\circledR} 1546$ a Meat Homogenate, NIST SRM ${ }^{\circledR} 1577 \mathrm{c}$ Freeze-Dried Bovine Liver, and NIST SRM ${ }^{\circledR} 1845$ a Whole Egg Powder), analyzed in select batches during the period of this study. The accuracy of $25(\mathrm{OH}) \mathrm{D}_{3}$ measurements was established in a previous report on eggs, which included recovery tests and the Pork/Egg CC (Exler et al., 2013), and also relative to consensus values for NIST SRM ${ }^{\circ} 1546$ a Meat Homogenate, SRM ${ }^{\oplus} 1845$ a Whole Egg Powder, and SRM ${ }^{\circ} 1577$ c FreezeDried Bovine Liver, obtained in the previous interlaboratory study (Roseland et al., 2016).

\subsection{Data analysis}

Means, standard deviations (SD), and RSDs were calculated using Microsoft $^{\oplus}$ Excel $^{\oplus} 2016$ (16.0.4266.1001) (Microsoft Corporation; Redmond, WA, USA). Analysis of Variance, Tukey's pairwise comparison of means, and Pearson correlation coefficients ( $\rho$ ) (Ott and Longnecker, 2016) were performed using XLSTAT (version 19.4.45826; Addinsoft, New York), with $\alpha=0.05$. However, statistical means comparisons were not possible in most cases, due to the necessarily limited number of samples (Section 2.1).

\section{Results and discussion}

\subsection{Quality control data}

The assayed vitamin $\mathrm{D}_{3}$ concentration in all certified reference materials was within the certified mean \pm uncertainty (Table 2). There are no food matrix reference materials with certified value for $25(\mathrm{OH})$ $\mathrm{D}_{3}$ (although, more recently NIST has reported a reference value for 25(OH)D $\mathrm{D}_{3}$ in SRM 1549 a Whole Milk Powder). Therefore, we relied on data for the Pork/Egg CC, SRM ${ }^{\circledR} 1546$ a Meat Homogenate, SRM ${ }^{\circledR} 1845$ a Whole Egg Powder, and SRM ${ }^{\circ} 1577$ c Freeze-Dried Bovine Liver previously characterized (Roseland et al., 2016), also validated by previously reported recovery studies for the Pork/Egg CC (Exler et al., 2013), to validate the accuracy of results during the period of this study. The assayed $25(\mathrm{OH}) \mathrm{D}_{3}$ was within the previously established tolerance limits for all of these materials (Table 2).
Because the Native food samples were analyzed over multiple assay batches, it was important to define and demonstrate the inter-assay precision, to establish uncertainty in mean values and enable comparison of vitamin D content among independent samples of a particular food or among different foods. Fig. 2 illustrates the precision of vitamin $\mathrm{D}_{3}$ and $25(\mathrm{OH}) \mathrm{D}_{3}$ analysis for the Salmon and Pork/Egg control materials; both had excellent precision over multiple analytical runs, with HorRat $<|1.0|$. The HorRat is a measure of the analytical precision demonstrated, relative to what is expected based on the concentration of the nutrient in the matrix, and should be between $|1.0|$ and $|2.0|$ (Horwitz and Albert, 2006). The HorRats for replicate analyses of samples are given in italics after the RSDs, in Table 3 , and ranged from 0.05 to 1.5 for vitamin $\mathrm{D}_{3}$ (mean, 0.6 ; median, 0.7 ), and from 0.06 to 1.4 for $25(\mathrm{OH}) \mathrm{D}_{3}$ (mean, 0.6; median, 0.5). These data demonstrate excellent precision of analyses across the range of sample matrices and analyte concentrations, and that data for different foods assayed in different batches can be compared with confidence that differences are not due to run-to-run analytical variability.

\subsection{Vitamin $D$ content of foods}

Vitamin $\mathrm{D}_{2}$ was $<0.1 \mu \mathrm{g} / 100 \mathrm{~g}$ in all cases. Although some vitamin $\mathrm{D}_{2}$ could be present in marine mammals and fish, due to diet (Roseland et al., 2018), it was not detected in samples analyzed in this study. Vitamin $D_{3}$ was $\geq 2 \mu \mathrm{g} / 100 \mathrm{~g}$ [ $\geq 13 \%$ of the DRI of $15 \mu \mathrm{g}$ (600 IU) set by IOM (2010)] in all of the foods except the land animals, bearded seal meat, and mature (but not young) bearded seal oil. More than $10 \mu \mathrm{g}$ (400 IU) vitamin $\mathrm{D}_{3}$ per $100 \mathrm{~g}$ was present in steelhead trout; dried sheefish, whitefish, and smelt; fermented sheefish eggs; salmon (including smoked salmon); and beluga whale and seal oils [except, interestingly, only in young bearded seal $(20 \mu \mathrm{g} / 100 \mathrm{~g})$ but not mature bearded seal oil $(0.29 \mu \mathrm{g} / 100 \mathrm{~g})]$. Many of the foods were significant sources of $25(\mathrm{OH}) \mathrm{D}_{3}$. The biological activity of $25(\mathrm{OH}) \mathrm{D}_{3}$ has been hypothesized to be potentially 1.7-5 times that of $\mathrm{D}_{3}$ (Bischoff-Ferrari et al., 2012; Jakobsen, 2007; Ovesen et al., 2003; Taylor et al., 2016), at least in part due to greater absorption relative to vitamin $\mathrm{D}_{3}$ (Borel et al., 2015). Using a potency of $5 x$ (to account for foods which cumulatively might contribute significant vitamin D activity), a $25(\mathrm{OH}) \mathrm{D}_{3}$ level $\geq 0.3 \mu$ g would represent at least $10 \%$ of the DRI for vitamin D. Foods containing $\geq 0.3 \mu \mathrm{g} 25(\mathrm{OH}) \mathrm{D}_{3}$ per $100 \mathrm{~g}$ were dried and smoked salmon; beluga whale dried meat, boiled skin and fat, and oil; and spotted seal oil. The highest levels of $25(\mathrm{OH}) \mathrm{D}_{3}(0.7-1.2 \mu \mathrm{g} / 100 \mathrm{~g})$ were in beluga whale skin and fat, dried meat, and oil, and in smoked red salmon. All of the land animals had vitamin $\mathrm{D}_{3}$ contents $<0.1$ and $25(\mathrm{OH}) \mathrm{D}_{3}$ contents $<0.2 \mu \mathrm{g} / 100 \mathrm{~g}$. There was no correlation between vitamin $\mathrm{D}_{3}$ and $25(\mathrm{OH}) \mathrm{D}_{3}$ concentrations within any of the groups of all samples, fish and marine mammal products only, or marine mammal products only ( $\rho=0.177, \rho=0.127$, and $\rho=-0.278$, respectively),

Table 2

Results for certified reference materials and control materials assayed with samples.

\begin{tabular}{|c|c|c|c|c|c|c|c|}
\hline \multirow[b]{2}{*}{ Material } & \multicolumn{6}{|c|}{ Assayed } & \multirow{2}{*}{$\begin{array}{l}\text { Expected } \\
\text { Range (mean } \pm \text { uncertainty }\end{array}$} \\
\hline & $n$ & Mean & $\% \mathrm{RSD}^{\mathrm{a}}$ & HorRat $^{\mathrm{b}}$ & Low & High & \\
\hline \multicolumn{8}{|l|}{ Vitamin $D_{3}$} \\
\hline NIST SRM ${ }^{\oplus}$ 1546a Meat Homogenate & 5 & 0.23 & 13.0 & 0.7 & 0.19 & 0.27 & $0.199-0.267$ \\
\hline NIST SRM ${ }^{\oplus} 1577$ c Freeze-Dried Beef Liver & 3 & $<0.05$ & & & $<0.05$ & $<0.05$ & $0.018-0.068$ \\
\hline NIST SRM ${ }^{\oplus} 1845$ a Whole Egg Powder & 3 & 4.42 & 1.8 & 0.1 & 4.33 & 4.48 & $4.04-4.94$ \\
\hline \multicolumn{8}{|l|}{$25(\mathrm{OH}) \mathrm{D}_{3}$} \\
\hline NIST SRM ${ }^{\oplus}$ 1546a Meat Homogenate & 6 & 0.08 & 19.7 & 0.8 & 0.06 & 0.10 & $0.07-0.11$ \\
\hline NIST SRM ${ }^{\oplus} 1577$ c Freeze-Dried Beef Liver & 3 & 1.42 & 5.3 & 0.4 & 1.34 & 1.49 & $1.30-1.72$ \\
\hline NIST SRM ${ }^{\oplus} 1845$ a Whole Egg Powder & 3 & 1.29 & 4.1 & 0.3 & 1.23 & 1.33 & $1.05-1.45$ \\
\hline
\end{tabular}

\footnotetext{
a Relative standard deviation.

b Assayed RSD/Expected RSD, with Expected RSD = [(Mean/100/1,000,000 $\left.)^{-0.1505}\right]$ (Horwitz and Albert, 2006).

c Roseland et al. (2016).
} 

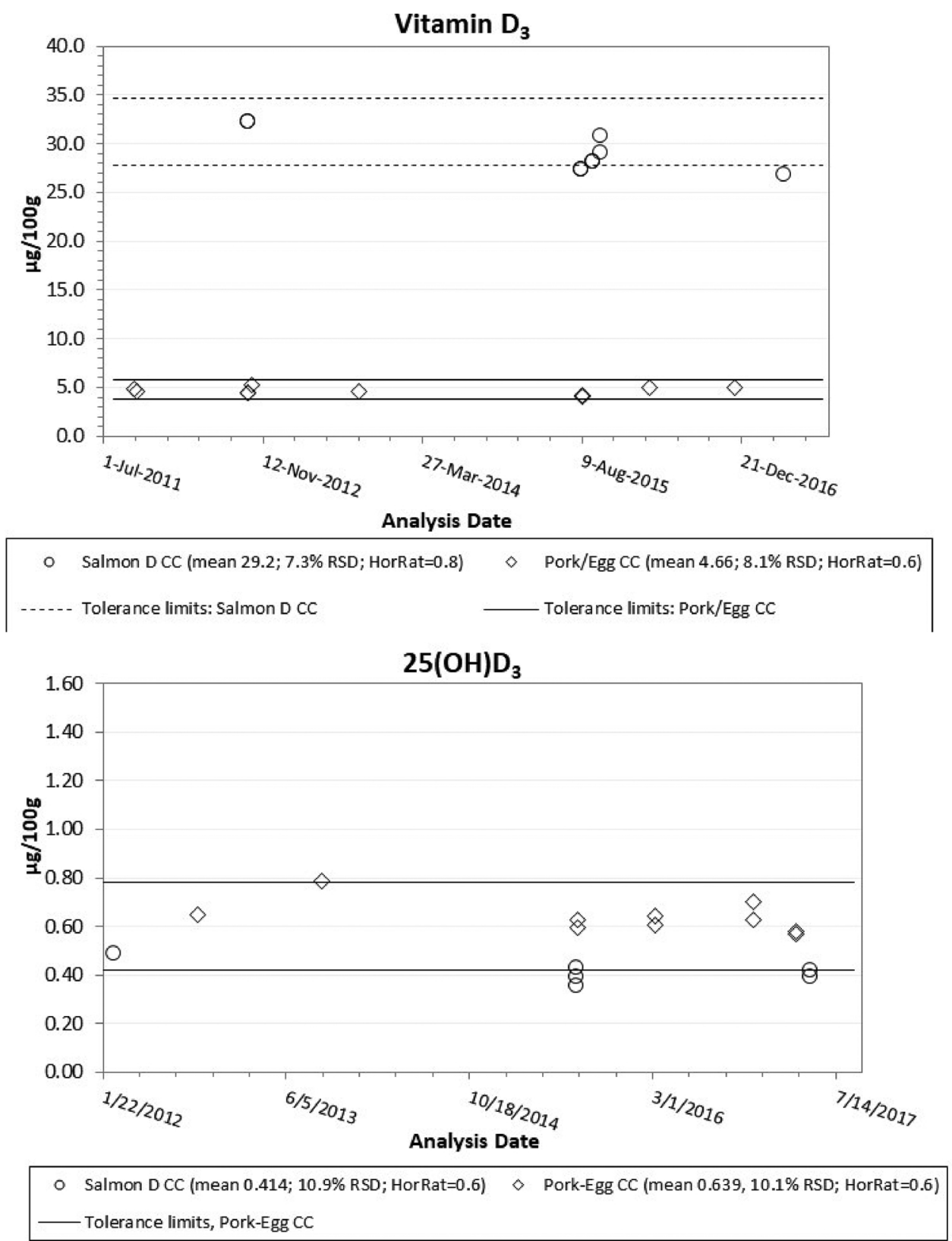

Fig. 2. Quality control data for vitamin $\mathrm{D}_{3}$ and 25-hydroxyvitamin $\mathrm{D}\left[25(\mathrm{OH}) \mathrm{D}_{3} 3\right]$ in two matrices, a composite of bratwurst sausage and egg yolks (Pork/Egg CC) and canned sockeye salmon (Salmon D CC). SD = standard deviation; RSD = relative standard deviation. HorRat = ratio of assayed to expected RSD, with expected RSD $=$ assayed mean $/\left((100 / 1,000,000)^{-0.1505}\right)$, according to Horwitz and Albert (2006).

but the relationship was generally positive among samples of fish $(\rho=0.759)$.

There was a wide range in vitamin $\mathrm{D}$ content among different samples for some foods, for which multiple samples were possible to collect [halibut $(n=4)$, dried and smoked salmon $(n=4)$, beluga whale skin and fat $(n=2)$, and young bearded seal oil $(n=2)]$. There was a striking difference in vitamin $\mathrm{D}_{3}$ content among samples of beluga whale skin and fat (2.97 and $10.0 \mu \mathrm{g} / 100 \mathrm{~g}$ ), although $25(\mathrm{OH}) \mathrm{D}_{3}$ content $(1.2 \mu \mathrm{g} / 100 \mathrm{~g})$ did not vary. Both $\mathrm{D}_{3}$ and $25(\mathrm{OH}) \mathrm{D}_{3}$ varied among samples of dried and smoked salmon (32.6-53.6 and $0.081-0.836 \mu \mathrm{g} / 100 \mathrm{~g}$, respectively) and were not related to moisture content $\left(39.8-67.8 \mu \mathrm{g} \mathrm{D}_{3}\right.$ and $0.112-1.06 \mu \mathrm{g} 25(\mathrm{OH}) \mathrm{D}_{3}$ per $100 \mathrm{~g}$ dry weight, respectively).

There are some publications that discuss possible reasons for variability in vitamin $\mathrm{D}$ between species and within different samples of food species (Kenny et al., 2004; Mattila et al., 1997; Pierens and
Fraser, 2015; Rao and Raghuramulu, 1996; Roseland et al., 2018), including variation in diet. Reports on vitamin D metabolism and content of marine mammals are more limited (Keiver et al., 1988; Kenny et al., 2004; Routti et al., 2010; Wilske and Arnbom, 1996). Seals belong to the suborder Pinnipedia, comprising flipper-footed marine animals [seals (Phocidfamily), sea lions (Otariid family), and walruses (Odobenid family)]; whales belong to the order Cetacea, that also includes dolphins and porpoises (Marine Mammal Center, 2016). Pinnepeds spend some time on land, and thus (in contrast to whales and fish), have the potential for cutaneous synthesis of vitamin D in addition to dietary sources. Wilske and Arnbom (1996) studied elephant seals and found two annual peaks in serum $25(\mathrm{OH}) \mathrm{D}_{3}$, occurring after periods of intensive exposure to UV radiation. Because the hunting season in far northern latitudes would be in the late spring-early fall, vitamin D stores in seals could be expected to build up over the summer and be higher in animals caught in late summer or fall. Thus, the low vitamin D 
Table 3

Vitamin $\mathrm{D}_{3}$ and 25-hydroxyvitamin $\mathrm{D}_{3}\left[25(\mathrm{OH}) \mathrm{D}_{3}\right]$ in traditional native meats, fish, and oils (SD, standard deviation; RSD, relative standard deviation).

\begin{tabular}{|c|c|c|c|c|c|c|c|c|c|c|c|c|c|}
\hline \multirow[b]{2}{*}{ Food } & \multirow[b]{2}{*}{$\begin{array}{l}\text { Sample } \\
\text { Code }^{\mathrm{a}}\end{array}$} & \multirow[b]{2}{*}{$\begin{array}{l}\text { Moisture (g/ } \\
100 \mathrm{~g})\end{array}$} & \multirow[b]{2}{*}{$\begin{array}{l}\text { Total Fat }(\mathrm{g} / \\
100 \mathrm{~g})\end{array}$} & \multicolumn{5}{|c|}{ Vitamin $D_{3}(\mu g / 100 g)$} & \multicolumn{5}{|c|}{$25(\mathrm{OH})$-Vitamin $\mathrm{D}_{3}(\mu \mathrm{g} / 100 \mathrm{~g})$} \\
\hline & & & & $\mathrm{n}^{\mathrm{b}}$ & mean & SD & $\%$ RSD & (HorRat $\left.{ }^{\mathrm{C}}\right)$ & $\mathrm{n}^{\mathrm{b}}$ & mean & SD & $\%$ RSD & $\left(\right.$ HorRat $\left.^{\mathrm{C}}\right)$ \\
\hline \multicolumn{14}{|l|}{ Fish } \\
\hline Halibut, wild - raw (Palmer, AK) & F1 & 77.3 & 0.74 & 2 & 3.66 & 0.48 & 13.1 & $(1.0)$ & 1 & 0.128 & & & \\
\hline \multirow{3}{*}{$\begin{array}{l}\text { Halibut, with skin -raw (Aleutian } \\
\text { Islands) }\end{array}$} & F2 & 76.3 & 1.46 & 1 & 6.54 & & & & 1 & $<0.100$ & & & \\
\hline & F3 & 71.0 & 3.58 & 2 & 5.82 & & & & 1 & 0.039 & & & \\
\hline & F4 & 69.2 & 5.92 & 1 & 4.85 & & & & 1 & $<0.100$ & & & \\
\hline $\begin{array}{l}\text { Halibut, with skin - cooked (Aleutian } \\
\text { Islands) }\end{array}$ & F5 & 73.3 & 1.14 & 1 & 5.47 & & & & na & & & & \\
\hline \multirow[t]{2}{*}{ Salmon, Chum - dried } & F6 & 18.1 & 18.2 & 1 & 32.6 & & & & 1 & 0.292 & & & \\
\hline & F7 & 27.4 & 10.6 & 2 & 43.8 & 3.5 & 8.0 & $(0.9)$ & 1 & 0.081 & & & \\
\hline \multirow[t]{2}{*}{ Salmon, Red - smoked } & F8 & 26.9 & 11.0 & 4 & 40.3 & 2.2 & 5.6 & $(0.6)$ & 1 & 0.778 & & & \\
\hline & F9 & 21.0 & 11.8 & 2 & 53.6 & 2.6 & 4.9 & $(0.6)$ & 2 & 0.836 & 0.190 & 22.8 & (1.4) \\
\hline Sheefish, midsection - baked & F10 & 66.2 & 7.68 & 2 & 12.7 & 0.4 & 3.3 & $(0.3)$ & 2 & 0.068 & 0.015 & 22.3 & $(0.9)$ \\
\hline Sheefish, raw & F11 & 74.6 & 2.84 & 2 & 13.8 & 0.1 & 0.5 & $(0.05)$ & 2 & 0.032 & & & \\
\hline Smelt - dried & F12 & 16.9 & 17.9 & 3 & 25.4 & 2.8 & 11.0 & (1.1) & 2 & $<0.100$ & & & \\
\hline Trout, Steelhead - boiled, canned & F14 & 70.6 & 8.26 & 1 & 11.1 & & & & 1 & 0.155 & & & \\
\hline Trout, Steelhead - dried & F13 & 6.49 & 8.06 & 2 & 19.2 & 0.3 & 1.5 & $(0.1)$ & 1 & 0.088 & & & \\
\hline Whitefish, filet - boiled & F15 & 75.7 & 2.38 & 1 & 2.11 & & & & 1 & $<0.100$ & & & \\
\hline Whitefish - baked & F16 & 68.4 & 10.8 & 2 & 8.80 & 0.75 & 8.5 & $(0.7)$ & 1 & 0.053 & & & \\
\hline Whitefish, raw - dried & F17 & 20.6 & 13.4 & 2 & 12.3 & 1.0 & 8.0 & $(0.7)$ & 1 & 0.110 & & & \\
\hline \multicolumn{14}{|l|}{ Fish Eggs } \\
\hline Whitefish, Broad - raw & FE1 & 68.9 & 0.76 & 2 & 3.62 & 0.45 & 12.5 & $(0.9)$ & 1 & $<0.100$ & & & \\
\hline Sheefish - fermented & FE2 & 67.7 & 5.86 & 2 & 17.7 & 1.7 & 9.6 & $(0.9)$ & 2 & $<0.100$ & & & \\
\hline \multicolumn{14}{|l|}{ Land Animals } \\
\hline Caribou, raw: ground & LA4 & 73.5 & 1.44 & 2 & $<0.1$ & & & & 2 & $<0.100$ & & & \\
\hline hind quarter & LA5 & 72.6 & 3.37 & 2 & $<0.1$ & & & & 2 & $<0.100$ & & & \\
\hline middle back & LA7 & 74.4 & 5.19 & 1 & $<0.1$ & & & & 2 & $<0.100$ & & & \\
\hline Caribou- boiled: flesh & LA3 & 58.4 & 6.26 & 2 & $<0.1$ & & & & 2 & $<0.100$ & & & \\
\hline rump, meat \& fat & LA1 & 26.2 & 58.5 & 2 & $<0.05$ & & & & 2 & $<0.100$ & & & \\
\hline Caribou - dried: meat/muscle & LA6 & 22.3 & 8.52 & 2 & $<0.1$ & & & & 2 & 0.024 & 0.009 & 38.1 & (1.4) \\
\hline shoulder blade/arm & LA8 & 33.8 & 3.67 & 3 & $<0.1$ & & & & 2 & $<0.100$ & & & \\
\hline rump \& hind - half dried & LA2 & 38.04 & 5.46 & 2 & $<0.1$ & & & & 2 & $<0.100$ & & & \\
\hline Goose, Canadian, boned flesh - boiled & LA9 & 59.9 & 6.29 & 2 & $<0.1$ & & & & 2 & 0.028 & 0.001 & 4.8 & $(0.2)$ \\
\hline Goose, Snow, boned flesh - boiled & LA10 & 57.4 & 8.63 & 2 & $<0.1$ & & & & 2 & 0.037 & 0.005 & 14.0 & $(0.5)$ \\
\hline \multicolumn{14}{|l|}{ Marine Mammals } \\
\hline Beluga Whale, meat - dried & MM3 & 21.5 & 8.37 & 2 & 2.01 & 0.10 & 4.9 & $(0.3)$ & 1 & 0.986 & & & \\
\hline Seal, Bearded, meat - dried & MM1 & 34.9 & 2.31 & 2 & $<0.1$ & & & & 2 & 0.102 & 0.002 & 2.1 & $(0.1)$ \\
\hline Seal, Bearded, meat - dried, in oil & MM2 & 35.5 & 25.1 & 2 & $<0.1$ & & & & 2 & $<0.055$ & & & \\
\hline \multirow[t]{2}{*}{ Whale, Beluga, skin \& fat - boiled } & MM4 & 54.4 & 27.5 & 3 & 10.0 & 0.7 & 7.4 & $(0.7)$ & 2 & 1.24 & 0.14 & 11.5 & $(0.7)$ \\
\hline & MM5 & 52.21 & 31.40 & 3 & 2.87 & 0.58 & 20.1 & (1.5) & 2 & 1.15 & 0.02 & 2.1 & $(0.1)$ \\
\hline \multicolumn{14}{|l|}{ Marine Mammal Oils \& Fats } \\
\hline Whale oil, Beluga, oil & MO6 & 0.15 & 97.5 & 4 & 7.11 & 0.34 & 4.8 & $(0.4)$ & 4 & 0.739 & 0.067 & 9.1 & $(0.5)$ \\
\hline Seal oil, Bearded & MO1 & $<0.1$ & 100 & 3 & 0.37 & & & & 3 & $<0.100$ & & & \\
\hline Seal oil, Bearded, young & MO2 & $<0.1$ & 99.4 & 1 & 19.5 & & & & 1 & $<0.100$ & & & \\
\hline Seal oil, Bearded, young & MO3 & $<0.1$ & 99.0 & 1 & 20.2 & & & & 1 & $<0.100$ & & & \\
\hline Seal oil, Ringed & MO4 & $<0.1$ & 98.0 & 2 & 29.0 & 0.3 & 1.0 & $(0.1)$ & 2 & $<0.100$ & & & \\
\hline Seal oil, Spotted & MO5 & 0.25 & 99.3 & 1 & 16.1 & & & & 1 & 0.628 & & & \\
\hline
\end{tabular}

a See Table 1 for descriptive information for the corresponding sample codes, where available.

b Number of analytical replicates.

c Ratio of assayed RSD to expected RSD, with expected RSD = assayed mean/((100/1000000) $\left.{ }^{-0.1505}\right)$, according to Horwitz and Albert (2006).

content of oil from the mature bearded seal but high content in the oil from young bearded seal (Table 3) might be due to the time of harvest (May for the mature seal, August for the young seals; see Table 1), rather than age of the animal. Kenny et al. (2004) found significant differences in vitamin D3 content of blubber among cetaceans and pinnepeds that was correlated with diet, with those primarily consuming invertebrates (e.g., bowhead whale, Pacific walrus) having lower vitamin $\mathrm{D}_{3}$ levels than those consuming primarily fish (e.g., beluga whale, ringed seal). However, in the present study, the vitamin D content of beluga whale oil, while high (mean, $7.11 \mu \mathrm{g} / 100 \mathrm{~g}$ ), was substantially lower than that of ringed seal oil $(29.0 \mu \mathrm{g} / 100 \mathrm{~g})$. One limitation of the present study (necessary due to the factors stated in Section 2.1) and others is that there are few samples per type of animal and lack of details on age, sex, time of harvest, and diet, so there are not enough data to draw conclusions about the relationship between vitamin D content and time of harvest, maturity of animal or other variables. These areas are worthy of further study.

\subsection{Nutritional significance}

In some Native Arctic populations, large quantities of wild caught foods, including salmon and other fish, contribute significantly to the diet (Ballew et al., 2006). Numerous researchers have reported improved vitamin D status and health outcomes in Native Alaskan and other Arctic populations consuming a diet rich in traditional foods (Andersen et al., 2013; Bersamin et al., 2007; Johnson et al., 2009; Kuhnlein et al., 2006; Luick et al., 2014; Mansuri et al., 2016; Mohatt et al., 2007; Murphy et al., 1995; Ryman et al., 2015; Sharma et al., 
a

Vitamin $\mathbf{D}_{3}$

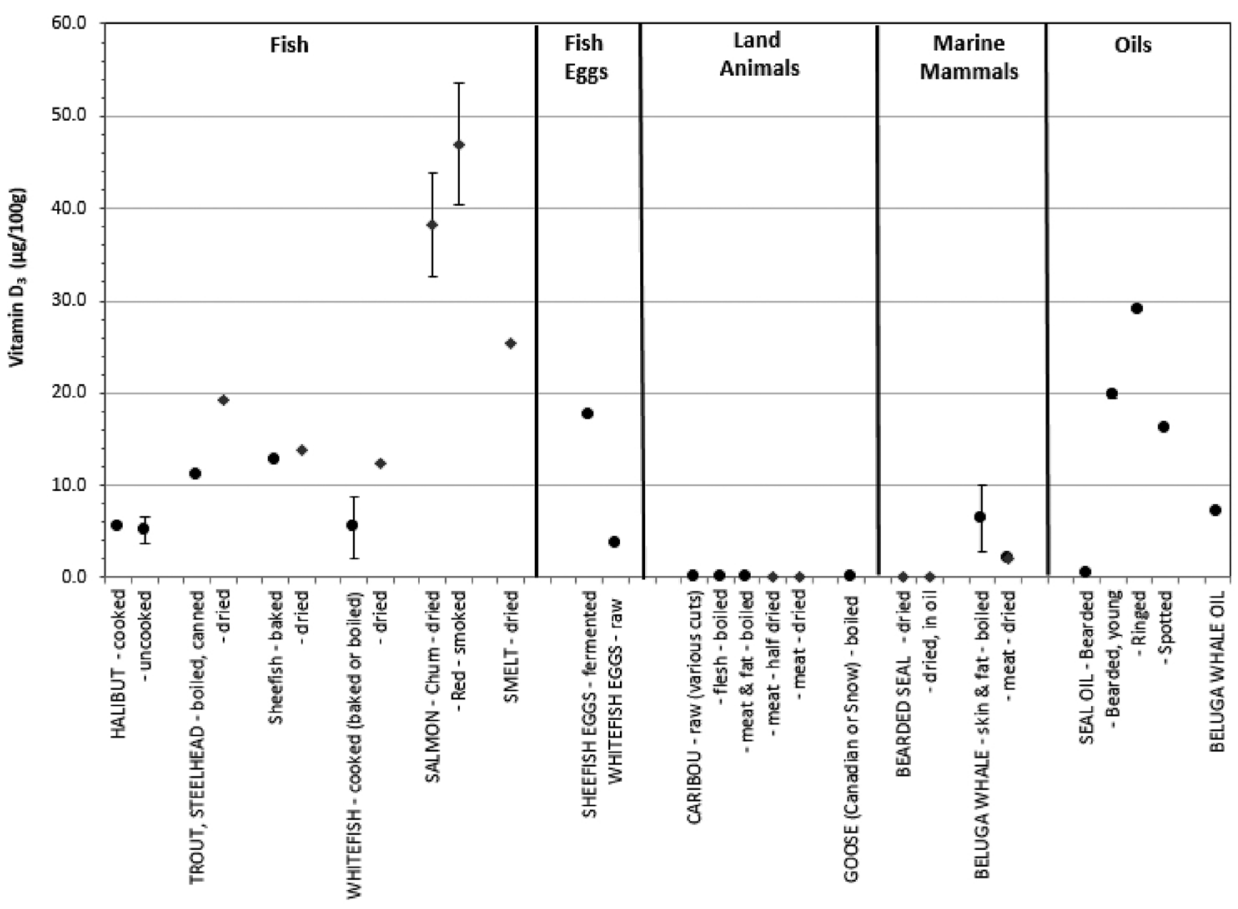

25(OH)Vitamin $D_{3}$

b

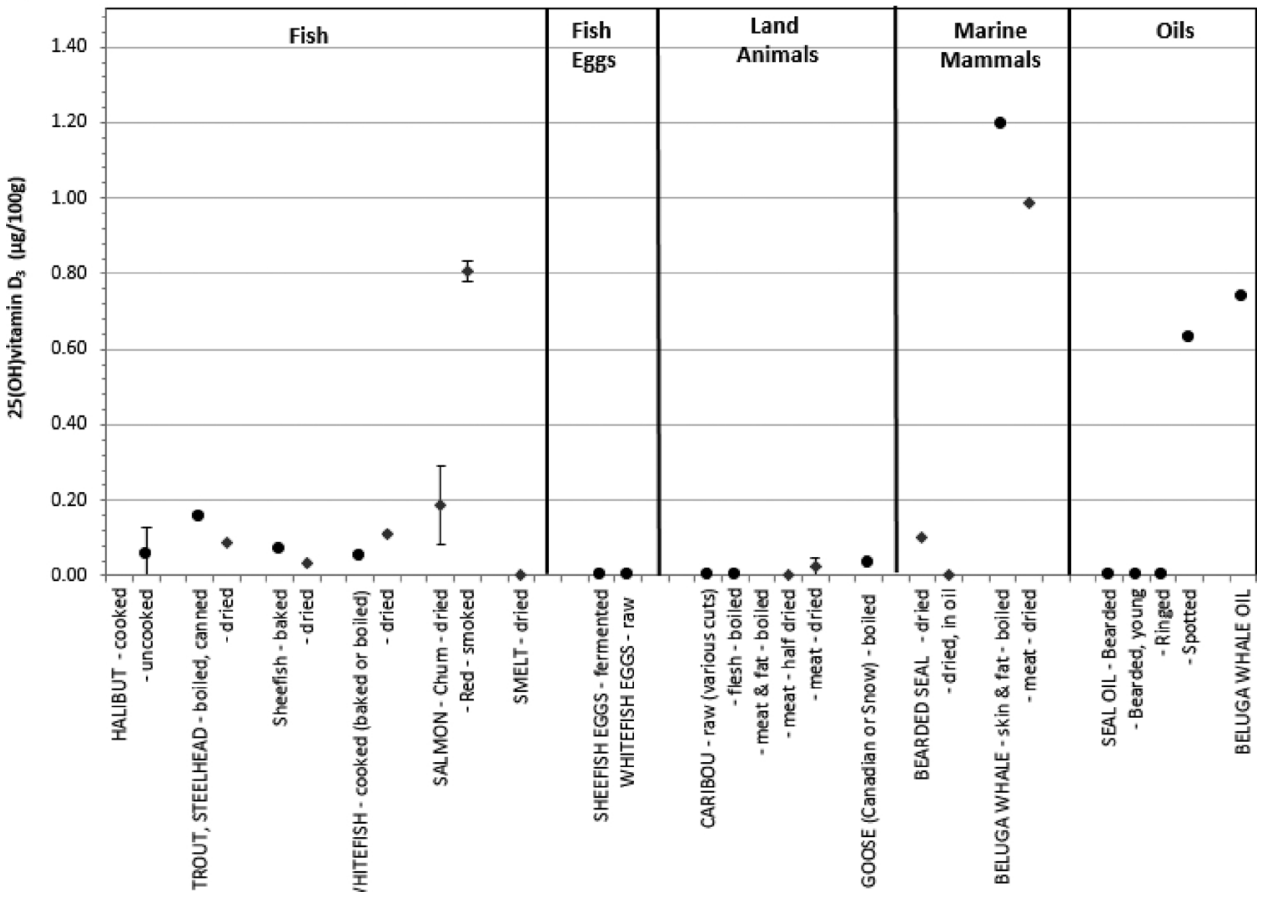

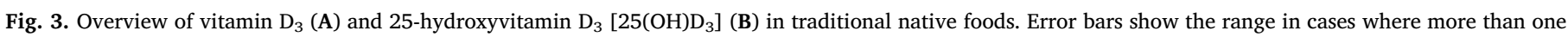
sample of a food was analyzed. $\downarrow$ indicates dried foods. The Daily Recommended Intake is $15 \mu \mathrm{g}$ (600 IU) (Institute of Medicine, 2011 ).

2011; Sheehy et al., 2014; Singleton et al., 2015). However, the conclusions about specific nutrient and health outcomes rest on the quality and completeness of food composition data, which are lacking (Taylor et al., 2016). Sharma et al. (2011) reviewed the association between lower risk of vitamin D deficiency and consumption of traditional foods in Arctic populations and suggested increasing the intake of fatty fish and marine mammals. However, in the present study, the vitamin $\mathrm{D}_{3}$ and fat contents among fish and marine mammal samples were not 

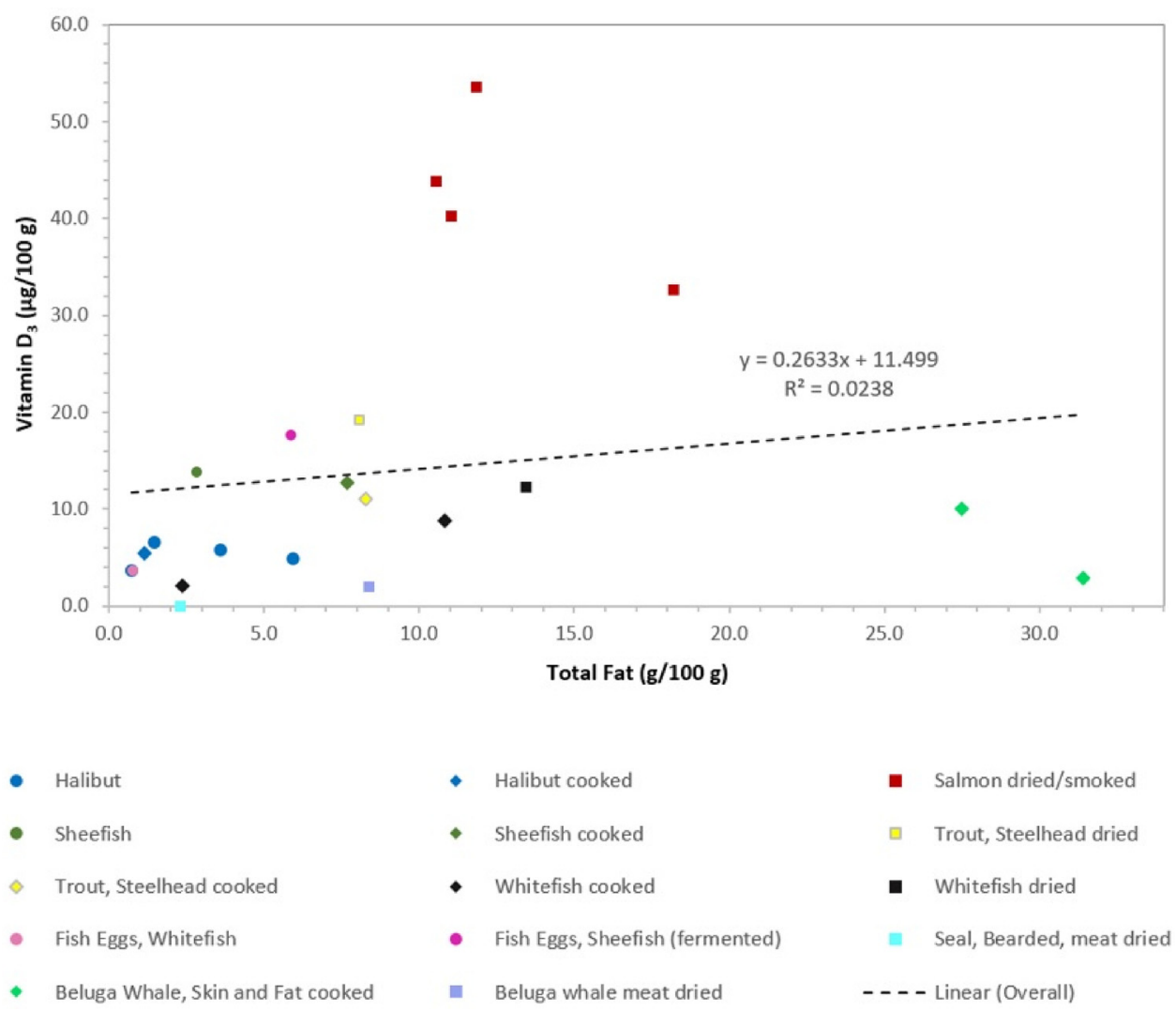

Fig. 4. Relationship between vitamin $\mathrm{D}_{3}$ and total fat contents in Native Alaskan fish and marine mammal foods (excluding oils).

highly correlated ( $\rho=0.154$; see Fig. 4 ), confounding the contention that "fatty fish" are the best sources of vitamin D, but consistent with a similar observation by Lu et al. (2007).

Additionally, within fish and marine mammals, certain species appear to be far better sources of vitamin D than others (Figs. 3 and 4). Of the fish, halibut and whitefish were relatively lower in vitamin D $\left(<10 \mu \mathrm{g} \mathrm{D}_{3}\right.$ and/or $<0.2 \mu \mathrm{g} 25(\mathrm{OH}) \mathrm{D}_{3}$ per $100 \mathrm{~g}$ ) than the other species [salmon, steelhead trout, sheefish, and dried fish (salmon, whitefish, sheefish, smelt)] that contained as much as $53.6 \mu \mathrm{g} \mathrm{D}_{3}$ and nearly $1 \mu \mathrm{g} 25(\mathrm{OH}) \mathrm{D}_{3}$ per $100 \mathrm{~g}$, equivalent to, per $85 \mathrm{~g}$ serving, more than $300 \%$ of the $15 \mu \mathrm{g}$ DRI specified by the Institute of Medicine (2011). Among different marine mammals and also within species, there were large inter-sample differences in some cases. For example, two samples of beluga whale skin and fat had 10.0 and $2.87 \mu \mathrm{g} \mathrm{D}_{3}$ and 1.24 and $1.15 \mu \mathrm{g} 25(\mathrm{OH}) \mathrm{D}_{3}$ per $100 \mathrm{~g}$, respectively. The sample of dried beluga whale meat was rich in vitamin $\mathrm{D}\left(8.37\right.$ and $0.986 \mu \mathrm{g} \mathrm{D}_{3}$ and $25(\mathrm{OH}) \mathrm{D}_{3}$ per $100 \mathrm{~g}$, respectively) compared to dried bearded seal meat, which had negligible vitamin $\mathrm{D}\left[\leq 0.1 \mu \mathrm{g} / 100 \mathrm{~g}\right.$ of both $\mathrm{D}_{3}$ and $\left.25(\mathrm{OH}) \mathrm{D}_{3}\right]$. In Fig. 5, vitamin D levels in the Alaskan Native foods and values in conventional alternatives [data from SR (USDA, 2016)] are compared.

Probably one of the most significant sources of vitamin D that would be unique to the Native diet is seal oil. In many traditional Native Alaskan households (e.g. Inuit and Yup'ik), it is used as a dipping sauce for bread and meats/fish, added to soups or stews, and in some traditional medicinal preparations (Magdanz and Wolfe, 1988 and Table 1). Among all samples analyzed, the ringed seal oil was one of the highest in vitamin $\mathrm{D}$, with $29.0 \mu \mathrm{g} \mathrm{D} \mathrm{D}_{3} / 100 \mathrm{~g}$, equivalent to $4.35 \mu \mathrm{g}$ per one $15 \mathrm{~g}$ ( $\sim 1$ tablespoon) serving ( $29 \%$ of the DRI). The content was substantially higher than beluga whale oil, although the latter was also a good source of vitamin D [7.11 $\mu \mathrm{g} \mathrm{D}_{3}$ and $\left.0.739 \mu \mathrm{g} 25(\mathrm{OH}) \mathrm{D}_{3} 100 \mathrm{~g}\right]$. However, there was one sample of bearded seal oil with $<0.5 \mu \mathrm{g} \mathrm{D} /$ $100 \mathrm{~g}$ ). Given the limited number of samples, it is possible that differences are not necessarily inter-species necessarily, but due to variation among individuals within a species, as discussed in Section 3.2.

The results of this survey study suggest the importance of collecting detailed information on intake of wild caught foods, including season, maturity, and preparation, and correlating those intakes with the corresponding food composition data reflecting factors that influence vitamin D content in individual animals, in epidemiological studies seeking to correlate nutrient intake with health outcomes in Native populations. For example, the average vitamin $\mathrm{D}_{3}$ content among all seal oil samples was $17.0 \mu \mathrm{g} / 100 \mathrm{~g}$, but the range was $0.37-29$ ( $<1$ to 4.35 per $15 \mathrm{~g}$ serving), and $25(\mathrm{OH}) \mathrm{D}_{3}$ was $<0.1 \mu \mathrm{g} / 100 \mathrm{~g}$ in all samples but one, which contained a meaningful amount $(0.628 \mu \mathrm{g} / 100 \mathrm{~g}$ ) (section 3.3). Considering its varied and widespread use and that it would be consumed in variable amounts and up to more than tens of grams per day, just monitoring intake of "seal oil" and an average value for vitamin D in seal oils could over- or underestimate vitamin D intake by more than $50 \%$ of the DRI if $30 \mathrm{~g}$ were consumed, based on the range found in samples in this study.

One point worth noting is the risk of pesticide residues (e.g., organohalogens) and heavy metals (e.g., mercury) that can accumulate in sea mammals, and in the case of organohalogens, concentrate in the fat (for example, see Brown et al., 2016; Gmelch et al., 2017; Laird et al., 2013; Pedro et al., 2017; Reiner et al., 2016). Data on potential toxic components in the marine mammal oils and fats consumed in particular populations would be beneficial to determine prior to recommending massive increases in consumption. Additionally, there have been cases of botulism from improper storage and handling of seal oil and dried meats (Bendinger, 2014; Centers for Disease Control and Prevention and Alaska Department of Health and Social Services, 2016; Dankmeyer, 2016) so attention should be paid to education in handling for food safety.

Table 4 summarizes vitamin D data for Arctic fish and marine mammal products from the literature compared to values from the present study of Alaskan Native foods. Differences in vitamin $\mathrm{D}_{3}$ were 


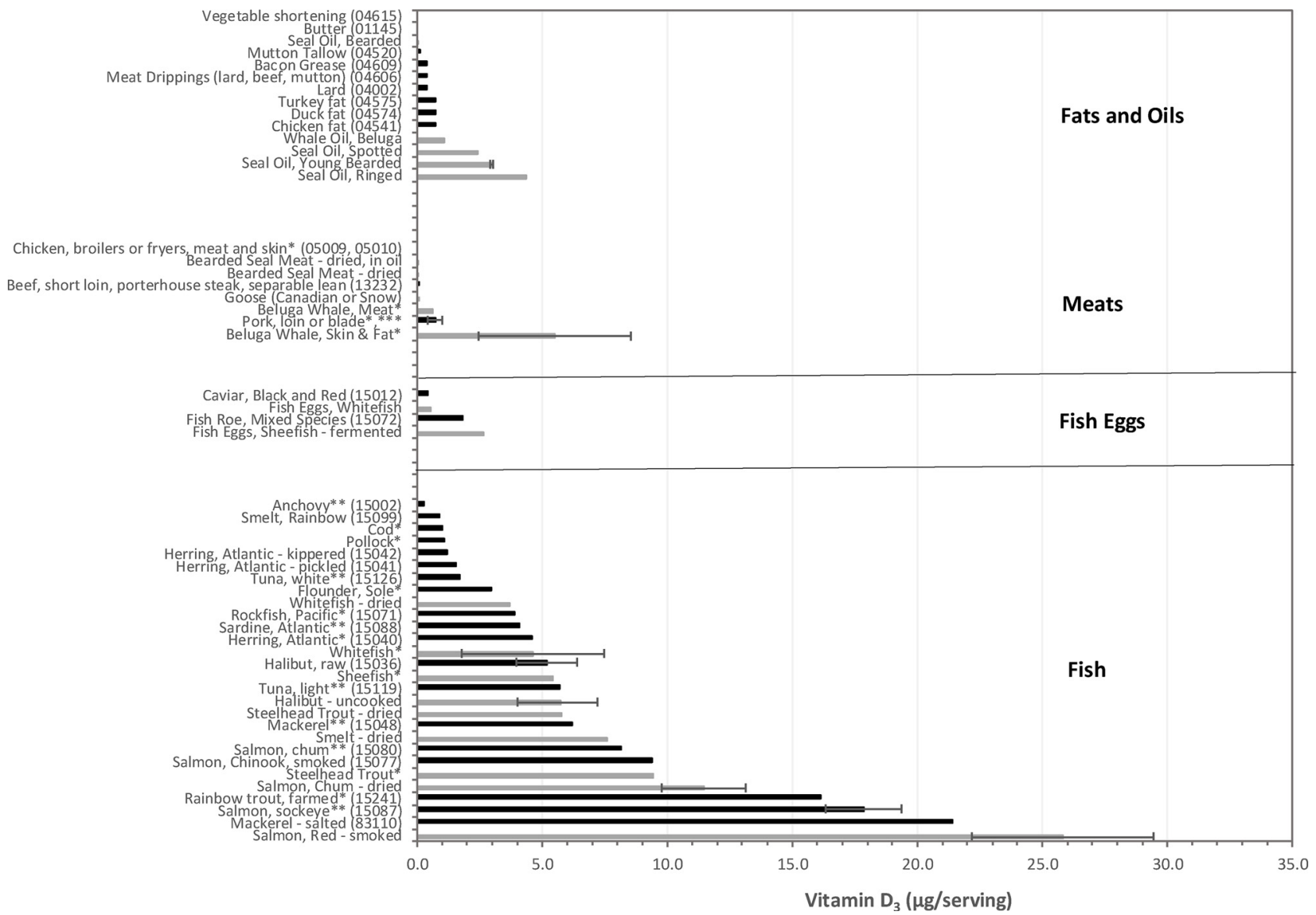

Fig. 5. Comparison of vitamin $D_{3}$ per serving in Native Alaskan traditional fish and marine mammal foods (n) with values for conventional alternatives (n) from the USDA National Nutrient Database for Standard reference (SR) (USDA, 2016) and the Dietary Reference Intake (- - -) (Institute of Medicine, 2011). NDB numbers from SR are given in parentheses for the conventional foods. Error bars show the range for traditional foods for which more than one sample was analyzed, and the standard error for values from SR. * cooked; ** canned; ***data are for cuts with similar fat content and are the mean and range for NDB numbers 10983 , 10984, 10985, 10986, 10987, 10988, 10990, 10991, 10992, 10993. Serving sizes are the Reference Amounts Customarily Consumed Per Eating Occasion (U.S. Food and Drug Administration, 2017 for fish and fish eggs; U.S. Food and Drug Administration, 2012) for meats and animal oils and fats: uncooked meats and fish, 110 g; cooked meats and fish, $85 \mathrm{~g}$; smoked salmon, $55 \mathrm{~g}$; dried fish, $30 \mathrm{~g}$; fish eggs, $15 \mathrm{~g}$; oils and fats, $15 \mathrm{~g}$. (No data for 25(OH) $\mathrm{D}_{3}$ available in SR as of 2017).

notable among studies/samples for seal oils and blubber $(1.6-160 \mu \mathrm{g} /$ $100 \mathrm{~g}$ for ringed seal and $<0.1-29.2 \mu \mathrm{g} / 100 \mathrm{~g}$ for bearded seal) and whale oil and blubber $(<1.6-74.4 \mu \mathrm{g} / 100 \mathrm{~g})$. It is difficult to determine whether the variability is due to actual within-species variation due to environment or maturity, for example (as discussed for variation among samples in this study, section 3.2 and in Roseland et al., 2018) or analytical differences, due to lack of reference samples in common that would quantify the contribution of any analytical variability, as discussed in other publications (Phillips et al., 2006; Phillips and Rasor, 2016; Roseland et al., 2016). The existing literature do not include data on $25(\mathrm{OH}) \mathrm{D}_{3}$, and some of the foods can be significant contributors $\left(>0.6 \mu \mathrm{g} / 100 \mathrm{~g}\right.$ ) (see Fig. 3). Thus, $25(\mathrm{OH}) \mathrm{D}_{3}$ should be included in food composition databases used to assess vitamin $\mathrm{D}$ intake in native populations.

The scarcity of data on vitamin D in Native foods makes it difficult to draw definitive conclusions about vitamin $\mathrm{D}$ intake and health in Native populations. Yet, hypotheses about diet and health, and epidemiological associations between food components and health outcomes, depend on complete and valid food composition data that are representative of the food supply of the population being studied. Without such data, it is not possible to reliably estimate nutrient intake or possible covariation of different components. For example, Adler et al. (1994) reported decreased prevalence of impaired glucose tolerance and diabetes associated with daily seal oil or salmon consumption by Alaska Natives, and attributed the effect to omega- 3 fatty acids.
However, in the present study, both of these foods were among the highest in vitamin $D_{3}(32.6-53.6$ and $16.1-29.9 \mu \mathrm{g} / 100 \mathrm{~g}$ (bearded, ring, and spotted seal), respectively) and $25(\mathrm{OH}) \mathrm{D}_{3}[0.081-0.836$ and 0.628 (spotted seal), respectively]. Whereas this does not prove cause and effect, possible associations between co-varying nutrients, particularly omega- 3 fatty acids and vitamin D, may be overlooked when food composition data are lacking.

Incomplete data on vitamin $\mathrm{D}$ in foods also means potential misestimation of vitamin $\mathrm{D}$ intake, particularly underestimation of the contribution of $25(\mathrm{OH}) \mathrm{D}_{3}$. Currently, SR does not contain data for $25(\mathrm{OH}) \mathrm{D}_{3}$, although it is planned to be included in future releases (Taylor et al., 2016). Data for vitamin $\mathrm{D}_{3}$ for only some of the samples were incorporated into SR beginning with release 19 (USDA, 2006) as part of the American Indian and Alaskan Native (AIAN) food composition database (Pehrsson et al., 2005a), due to the limited resources and quality of analytical methods available at the time. Many other food composition databases that have been used for dietary intake studies (e.g., Jakobsen and Saxholt, 2009; Lamberg-Allardt, 2006; Mileševića et al., 2018; Neufingerl et al., 2016; Ovesen et al., 2003) also have not contained data for $25(\mathrm{OH}) \mathrm{D}_{3}$. Recently, improved analytical methodology, including for $25(\mathrm{OH}) \mathrm{D}_{3}$, has allowed USDA to analyze more foods for both vitamin $\mathrm{D}_{3}$ and $25(\mathrm{OH}) \mathrm{D}_{3}$ (Roseland et al., 2016). Currently, the USDA is transitioning to a larger, more comprehensive food composition database, that will eventually include $25(\mathrm{OH}) \mathrm{D}_{3}$ values. 
Table 4

Summary and comparison of data from this study to data from the literature for Arctic marine mammals and fish.

\begin{tabular}{|c|c|c|c|c|c|c|c|c|c|c|c|}
\hline \multirow[b]{3}{*}{ Food } & \multicolumn{9}{|c|}{ Vitamin $\mathrm{D}_{3} \mu \mathrm{g} / 100 \mathrm{~g}$} & \multirow{2}{*}{\multicolumn{2}{|c|}{$\begin{array}{l}25(\mathrm{OH}) \mathrm{D}_{3} \mu \mathrm{g} / 100 \mathrm{~g} \\
\text { This study }\end{array}$}} \\
\hline & \multicolumn{3}{|c|}{ Kuhnlein et al. (2006) } & \multicolumn{3}{|c|}{ Kenny et al. (2004) } & \multicolumn{3}{|c|}{ This study } & & \\
\hline & $n$ & Mean & (Range) & $n$ & Mean & (Range) & $n$ & Mean & (Range) & Mean & (Range) \\
\hline \multicolumn{12}{|l|}{ Marine Mammal Meats } \\
\hline \multicolumn{12}{|l|}{ Seal } \\
\hline Flesh, boiled & 1 & 1.8 & & & & & & & & & \\
\hline $\begin{array}{l}\text { Flesh, dried } \\
\text { Ringed seal: }\end{array}$ & & & & & & & 1 & $<0.1$ & & 0.102 & \\
\hline Flesh, raw & 3 & $<1.6$ & & & & & & & & & \\
\hline \multicolumn{12}{|l|}{ Beluga Whale } \\
\hline Flesh, dried & & & & & & & 1 & 2.01 & & 0.986 & \\
\hline Skin, boiled & 2 & $<1.6$ & & & & & & & & & \\
\hline Skin, raw & 1 & 1.8 & & & & & & & & & \\
\hline \multicolumn{12}{|l|}{ Fish } \\
\hline \multicolumn{12}{|l|}{ Trout } \\
\hline Lake & 3 & 19.7 & $(3.7-37.1)$ & & & & & & & & \\
\hline Steelhead, boiled & & & & & & & 1 & 11.1 & & 0.155 & \\
\hline Steelhead, dried & & & & & & & 1 & 19.2 & & 0.088 & \\
\hline \multicolumn{12}{|l|}{ Whitefish } \\
\hline Flesh, raw & 2 & 4.4 & $(3.5-5.0)$ & 6 & 5.5 & $(4.2-7.3)$ & & & & & \\
\hline Flesh, raw, dried & & & & & & & 1 & 12.3 & & 0.110 & \\
\hline Flesh, baked or boiled & & & & & & & 2 & 5.45 & $(2.11-8.80)$ & 0.053 & $(<0.1-0.053)$ \\
\hline Arctic char & 4 & 25.8 & $(9.3-62.0)$ & 2 & 4.2 & $(4.0-4.3)$ & & & & & \\
\hline \multicolumn{12}{|l|}{ Salmon } \\
\hline Pink, raw & & & & 4 & 8.975 & $(6.1-13.4)$ & & & & & \\
\hline Red, dried or smoked & & & & & & & 2 & 47.0 & $(40.3-53.6)$ & 0.807 & $(0.778-0.836)$ \\
\hline Chum, dried & & & & & & & 2 & 38.2 & $(32.6-43.8)$ & 0.187 & $(0.081-0.292)$ \\
\hline Sheefish & & & & & & & & & & & \\
\hline Baked & & & & & & & 2 & 6.4 & $(<0.1-12.7)$ & 0.068 & $(0.057-0.079)$ \\
\hline Dried & & & & & & & 1 & 13.8 & & 0.032 & \\
\hline Smelt, dried & & & & & & & 1 & 25.4 & & $<0.1$ & \\
\hline Halibut, raw & & & & & & & 4 & 5.22 & $(3.66-6.54)$ & 0.057 & $(<0.1-0.128)$ \\
\hline Sculpin & & & & & & & & & & & \\
\hline Raw & 1 & 14.1 & & 5 & 4.78 & $(2.1-8.1)$ & & & & & \\
\hline Boiled & 1 & 2 & & & & & & & & & \\
\hline Cisco & & & & & & & & & & & \\
\hline Raw & & & & 5 & 4.7 & $(2.5-7.1)$ & & & & & \\
\hline Fish Eggs & & & & & & & & & & & \\
\hline Loche & 2 & 15.2 & $(13.0-17.4)$ & & & & & & & & \\
\hline Cisco & 2 & 6.5 & $(5.2-7.8)$ & & & & & & & & \\
\hline Whitefish (broad) & & & & & & & 1 & 3.62 & & $<0.1$ & \\
\hline Sheefish, fermented & & & & & & & 1 & 17.7 & & $<0.1$ & \\
\hline Marine Mammal Oils an & ats: & & & & & & & & & & \\
\hline $\begin{array}{l}\text { Seal } \\
\quad \text { Bearded: }\end{array}$ & & & & & & & & & & & \\
\hline Blubber, raw & & & & 6 & 15.7 & $(1.1-29.2)$ & & & & & \\
\hline Oil (from mature seal) & & & & & & & 1 & $<0.1$ & & $<0.1$ & \\
\hline $\begin{array}{l}\text { Oil (from young seal) } \\
\text { Ringed: }\end{array}$ & & & & & & & 2 & 19.9 & $(19.5-20.2)$ & $<0.1$ & \\
\hline Blubber, raw & 1 & 1.6 & & 7 & 74.7 & $(13.8-160)$ & & & & & \\
\hline $\begin{array}{l}\text { Oil } \\
\text { Spotted }\end{array}$ & & & & & & & 1 & 29 & & $<0.1$ & \\
\hline Oil & & & & & & & 1 & 16.1 & & 0.628 & \\
\hline Walrus & & & & & & & & & & & \\
\hline Blubber, raw & & & & 7 & 0.54 & $(0.3-0.9)$ & & & & & \\
\hline Whale & & & & & & & & & & & \\
\hline Beluga: & & & & & & & & & & & \\
\hline Blubber, boiled & 1 & 13.3 & & & & & $2^{\mathrm{a}}$ & 6.46 & $(2.87-10.0)$ & 1.20 & $(1.15-1.24)$ \\
\hline Blubber, raw & 2 & $<1.6$ & & 6 & 42.6 & $(22.5-74.4)$ & & & & & \\
\hline Oil & 1 & 26.7 & & & & & 1 & 7.11 & & 0.739 & \\
\hline Bowhead: & & & & & & & & & & & \\
\hline Blubber, raw & & & & 5 & 0.42 & $(0.3-0.6)$ & & & & & \\
\hline
\end{tabular}

a Skin and fat.

\subsection{Limitations and future research}

The number of samples analyzed was necessarily limited by the fact that the foods given for analysis were from the Native hunted food supply, and intensive sampling would impact tribal food security.
Nonetheless, the wide range of vitamin $\mathrm{D}$ content among the marine mammal products, likely reflecting influences of species, maturity, environment, and season and the seasonality of food harvesting and consumption in these populations, suggests the importance of population-specific sampling of the food supply that reflects these variables. 
The preliminary data from this study has pointed towards more intensive sampling of marine mammals and oils as most critical in obtaining accurate estimates of vitamin D intake, along with addressing other challenges that have been described for nutritional epidemiology in Native populations (Amy and Pehrsson, 2003; Fialkowski et al., 2010; Pehrsson et al., 2005a, b; Ryman et al., 2015; Sheehy et al., 2013; Standlee-Strom, 2016).

\section{Declarations of interest}

None.

\section{Acknowledgments}

This work was supported by cooperative agreements 58-1235-2$111,58-1235-3-128$, and 58-8040-5-118 between the USDA Agricultural Research Service Nutrient Data Laboratory and Virginia Tech, including funds from interagency agreements between USDA and the National Cancer Institute (NCI) and the National Institute of Diabetes Digestive and Kidney Diseases (NIDDK). Amy Rasor, Nancy Conley, and Ryan McGinty assisted with sample preparation.

\section{Appendix A. Supplementary data}

Supplementary material related to this article can be found, in the online version, at doi:https://doi.org/10.1016/j.jfca.2018.09.008.

\section{References}

Adler, A.I., Boyko, E.J., Schraer, C.D., Murphy, N.J., 1994. Lower prevalence of impaired glucose tolerance and diabetes associated with daily seal oil or salmon consumption of Alaska natives. Diabetes Care 17, 1498-1501.

Ahuja, J.K., Moshfegh, A.J., Holden, J.M., Harris, E., 2013. USDA food and nutrient databases provide the infrastructure for food and nutrition research, policy, and practice. J. Nutr. 143, 241S-249S.

Amy, L.A., Pehrsson, P.R., 2003. Development of the American Indian and Alaska native foods database: status report. Presented at the American Dietetic Association's Food Nutrition Conference Exhibition Retrieved October 13, 2017 from: https://www.ars. usda.gov/ARSUserFiles/80400525/Articles/ADA2003_NativeAmerican.pdf.

Andersen, S., Laurberg, P., Hvingel, B., Kleinschmidt, K., Heickendorff, L., Mosekilde, L., 2013. Vitamin D status in Greenland is influenced by diet and ethnicity: a populationbased survey in an Arctic society in transition. Br. J. Nutr. 109, 928-935.

AOAC, 2005a. Method 950.46 (39.1.02) moisture in meat. Official Methods of Analysis, 15 th ed. Association of Official Analytical Chemists International, Gaithersburg, MD.

AOAC, 2005b. 954.02 (4.5.02 or 7.063) fat (crude) or ether extract in pet food. Official Methods of Analysis, 15th ed. Association of Official Analytical Chemists International, Gaithersburg, MD.

Ballew, C., Tzilkowski, A.R., Hamrick, K., Nobmann, E.D., 2006. The contribution of subsistence foods to the total diet of Alaska natives in 13 rural communities. Ecol. Food Nutr. 45, 1-26.

Barake, R., Weiler, H., Payette, H., Gray-Donald, K., 2010. Vitamin D status in healthy free-living elderly men and women living in Quebec, Canada. J. Am. Coll. Nutr. 29, 25-30.

Barnkob, L.L., Argyraki, A., Petersen, P.M., Jakobsen, J., 2016. Investigation of the effect of UV-LED exposure conditions on the production of vitamin D in pig skin. Food Chem. 212, 386-391.

Bendinger, D., 2014. Tainted Seal Oil Linked to Botulism Outbreak in Southwest Alaska (updated September 28, 2016). Retrieved October 13, 2017 from:. Alaska Dispatch News. https://www.adn.com/health/article/tainted-seal-oil-linked-botulismoutbreak-southwest-alaska/2014/12/25/.

Bersamin, A., Zidenberg-Cherr, S., Stern, J.S., Luick, B.R., 2007. Nutrient intakes are associated with adherence to a traditional diet among Yup'ik Eskimos living in remote Alaska native communities: the CANHR study. Int. J. Circump. Health 66, $62-70$.

Bischoff-Ferrari, H.A., Dawson-Hughes, B., Stöcklin, E., Sidelnikov, E., Willett, W.C., Orav, E.J., Stähelin, H.B., Wolfram, S., Jetter, A., Schwager, J., Henschkowski, J., von Eckardstein, A., Egli, A., 2012. Oral supplementation with $25(\mathrm{OH}) \mathrm{D}(3)$ versus vitamin D(3): effects on 25(OH)D levels, lower extremity function, blood pressure and markers of innate immunity. J. Bone Miner. Res. 27, 160-169.

Borel, P., Caillaud, D., Cano, N.J., 2015. Vitamin D bioavailability: state of the art. Crit. Rev. Food Sci. Nutr. 55, 1193-1205.

Brown, T.M., Fisk, A.T., Wang, X., Ferguson, S.H., Young, B.G., Reimer, K.J., Muirc, D.C.G., 2016. Mercury and cadmium in ringed seals in the Canadian arctic: influence of location and diet. Sci. Total Environ. 545-546, 503-511.

Byrdwell, W.C., 2009. Comparison of analysis of vitamin $\mathrm{D}_{3}$ in foods using ultraviolet and mass spectrometric detection. J. Agric. Food. Chem. 57, 2135-2146.

Byrdwell, W.C., DeVries, J., Exler, J., Harnly, J.M., Holden, J.M., Holick, M.F., Hollis, B.W., Horst, R.L., Lada, M., Lemar, L.E., 2008. Analyzing vitamin D in foods and supplements: methodologic challenges. Am. J. Clin. Nutr. 88, 554S-557S.
Byrdwell, W.C., Harnly, J.M., Exler, J., Patterson, K.Y., Phillips, K.M., Holden, J.M., 2013. Vitamin D levels in fish and shellfish determined by liquid chromatography with ultraviolet detection and mass spectrometry. J. Food Compos. Anal. 30, 109-119.

Cashman, K.D., Seamans, K.M., Lucey, A.J., Stöcklin, E., Weber, P., Kiely, M., Hill, T.R., 2012. Relative effectiveness of oral 25-hydroxyvitamin $D_{3}$ and vitamin $D_{3}$ in raising wintertime serum 25-hydroxyvitamin D in older adults. Am. J. Clin. Nutr. 95, 1350-1356.

Centers for Disease Control and Prevention, Arctic Investigations Program and Alaska Department of Health and Social Services Division of Public Health, Section of Epidemiology, 2016. Alaska Native Foods, Published July 26, 2017. Retrieved October 13, 2017 from: https://cdc.gov/botulism/botulism-alaska-foods.html.

Chen, T.C., Chimeh, F., Lu, Z., Mathieu, J., Person, K.S., Zhang, A., Kohn, N., Martinello, S., Berkowitz, R., Holick, M.F., 2007. Factors that influence the cutaneous synthesis and dietary sources of vitamin D. Arch. Biochem. Biophys. 460, 213-217.

Clausen, I., Jakobsen, J., Leth, T., Ovesen, L., 2003. Vitamin $\mathrm{D}_{3}$ and 25-hydroxyvitamin $\mathrm{D}_{3}$ in raw and cooked pork cuts. J. Food Compos. Anal. 16, 575-585.

Dankmeyer, C., 2016. Seal Oil Team 6, Alaska Environmental Health Association. Retrieved October 13, 2017 from: https://aehablog.wordpress.com/2016/04/29/ seal-oil-team-6/. https://sites.google.com/site/aehatest/about-us.

Exler, J., Phillips, K.M., Patterson, K.Y., Holden, J.M., 2013. Cholesterol and vitamin D content of eggs in the U.S. retail market. J. Food Compos. Anal. 29, 110-116.

Fialkowski, M.K., McCrory, M.A., Roberts, S.M., Tracy, J.K., Grattan, L.M., Boushey, C.J., 2010. Estimated nutrient intakes from food generally do not meet dietary reference iDietary Reference Intakes among adult members of Pacific Northwest tribal nations. J. Nutr. 140, 992-998.

Frost, J.T., Hill, L., 2008. Vitamin D deficiency in a non-random sample of southeast Alaska natives. J. Am. Diet. Assoc. 108, 1508-1511.

Gmelch, L., Hintelmann, H., Hickie, B., Kienberger, H., Stern, G., Rychlik, M., 2017. Risk-benefit assessment of monomethylmercury and omega-3 fatty acid intake for ringed seal consumption with particular emphasis on vulnerable populations in the western Canadian Arctic. Front. Nutr. 4. Retrieved October 13, 2017 from: https:// doi.org/10.3389/fnut.2017.00030.

Haytowitz, D.B., Pehrsson, P.R., 2018. USDA's National Food and Nutrient Analysis Program (NFNAP) produces high-quality data for USDA food composition databases: two decades of collaboration. Food Chem. 238, 134-138.

Haytowitz, D.B., Pehrsson, P.R., Holden, J.M., 2008. The National Food and Analysis Program: a decade of progress. J. Food Compos. Anal. 21, S94-S102.

Holden, J.M., Lemar, L.E., Exler, J., 2008. Vitamin D in foods: development of the US Department of Agriculture database. Am. J. Clin. Nutr. 87, 1092S-1096S.

Holick, M.F., 2005. The vitamin D epidemic and its health consequences. J. Nutr. 35 , 2739S-2748S.

Horwitz, W., Albert, R., 2006. The Horwitz ratio (HorRat): a useful index of method performance with respect to precision. J. Assoc. Off. Anal. Chem. Int. 89, 1095-1109.

Huang, M., LaLuzerne, P., Winters, D., Sullivan, D., 2009. Measurement of vitamin D in foods and nutritional supplements by liquid chromatography/tandem mass spectrometry. J. Assoc. Off. Anal. Chem. Int. 92, 1327-1335.

Institute of Medicine, 2011. Dietary Reference Intakes for Vitamin D and Calcium. Available at. National Academies Press, Washington, DC (Accessed July 10, 2017). http://www.nationalacademies.org/hmd/Reports/2010/Dietary-Reference-Intakesfor-Calcium-and-Vitamin-D/DRI-Values.aspx.

Jakobsen, J., 2007. Bioavailability and bioactivity of vitamin $\mathrm{D}_{3}$ active compounds which potency should be used for 25-hydroxyvitamin $\mathrm{D}_{3}$ ? Int. Congress Ser. 1297, $133-142$.

Jakobsen, J., Knuthsen, P., 2014. Stability of vitamin D in foodstuffs during cooking. Food Chem. 148, 170-175.

Jakobsen, J., Saxholt, E., 2009. Vitamin D metabolites in bovine milk and butter. J. Food Compos. Anal. 22, 472-478.

Johnson, J.S., Nobmann, E.D., Asay, E., Lanier, A.P., 2009. dietary intake of Alaska native people in two regions and implications for health: the Alaska Native Dietary and Subsistence Food Assessment project. Int. J. Circump. Health 68, 109-122.

Keiver, K.M., Ronald, K., Draper, H.H., 1988. Plasma levels of vitamin D and some metabolites in marine mammals. Can. J. Zool. 66, 1297-1300.

Kenny, D.E., O’Hara, T.M., Chen, T.C., Lu, Z., Tian, X., Holick, M.F., 2004. Vitamin D content in Alaskan arctic zooplankton, fishes, and marine mammals. Zoo Biology 23 33-43.

Kuhnlein, H.V., Receveur, O., 1996. Dietary change and traditional food systems of in digenous peoples. Annu. Rev. Nutr. 16, 417-442.

Kuhnlein, H.V., Barthet, V., Farren, A., Falahi, E., Leggee, D., Receveur, O., Berti, P., 2006. Vitamins A, D, and E in Canadian Arctic traditional food and adult diets. J. Food Compos. Anal. 19, 495-506.

Laird, B.D., Goncharov, A.B., Egeland, G.M., Chan, H.M., 2013. Dietary advice on Inuit traditional food use needs to balance benefits and risks of mercury, selenium, and n3 fatty acids. J. Nutr. 143, 923-930.

Lamberg-Allardt, C., 2006. Vitamin D in foods and as supplements. Prog. Biophys. Mol. Biol. 92, 33-38.

Lebrun, J.B., Moffatt, M.E., Mundy, R.J., Sangster, R.K., Postl, B.D., Dooley, J.P., 1993. Vitamin D deficiency in a Manitoba community. Can. J. Public Health 84, 394-396.

Liu, J., Greenfield, H., Strobel, N., Fraser, D.R., 2013. The influence of latitude on the concentration of vitamin $\mathrm{D}_{3}$ and 25-hydroxy-vitamin $\mathrm{D}_{3}$ in Australian red meat. Food Chem. 140, 432-435.

Lu, Z., Chen, T.C., Zhang, A., Persons, K.S., Kohn, N., Berkowitz, R., Martinello, S., Holick, M.F., 2007. An evaluation of the vitamin $D_{3}$ content in fish: is the vitamin D content adequate to satisfy the dietary requirement for vitamin D? J. Steroid Biochem. Mol. Biol. 103, 642-644.

Luick, B., Bersamin, A., Stern, J.S., 2014. Locally harvested foods support serum 25-hydroxyvitamin D sufficiency in an indigenous population of Western Alaska. Int. J. Circump. Health 73 (1), 22732. https://doi.org/10.3402/ijch.v73.22732. Retrieved March 10, 2017.

Magdanz, J., Wolfe, R.J., 1988. The Production and Exchange of Seal Oil in Alaska. Special Publication No. SP1988-001. Alaska Department of Fish and Game, Division 
of Subsistence, Juneau, AK. Retrieved October 12, 2017 from: http://www.adfg. alaska.gov/specialpubs/SP2_SP1988-001.pdf.

Mansuri, S., Badawi, A., Kayaniyil, S., Cole, D.E., Harris, S.B., Mamakeesick, M., Wolever, T., Gittelsohn, J., Maguire, J.L., Connelly, P.W., Zinman, B., Hanley, A.J., 2016. Traditional foods and 25(OH)D concentrations in a subarctic First Nations community. Int. J. Circump. Health 75, 31956. https://doi.org/10.3402/ijch.v75.31956. Retrieved March 10, 2017 from:

Marine Mammal Center, 2016. Introduction to Marine Mammals. Retrieved July 25, 2017 from:. http://www.marinemammalcenter.org/education/marine-mammalinformation/.

Mattila, P., Piironen, V., Uusi-Rauva, E., Koivistoinen, P., 1995. Cholecalciferol and 25 hydroxycholecalciferol contents in fish and fish products. J. Food Compos. Anal. 8 , 232-243.

Mattila, P., Piironen, V., Haapala, R., Hirvi, T., Uusi-Rauva, E., 1997. Possible factors responsible for the high variation in the cholecalciferol contents of fish. J. Agric. Food. Chem. 45, 3891-3896.

Mattila, P., Ronkainen, R., Lehikoinen, K., Piironen, V., 1999. Effect of household cooking on the vitamin D content in fish, eggs, and wild mushrooms. J. Food Compos. Anal. $12,153-160$.

Mileševića, J., Samaniego, L., Kiely, M., Glibetić, M., Roe, M., Finglas, P., 2018. Specialized food composition dataset for vitamin D content in foods based on European standards: application to dietary intake assessment. Food Chem. 240, 544-549.

Mohatt, G.V., Plaetke, R., Klejka, J., Luick, B., Lardon, C., Bersamin, A., Hopkins, S., Dondanville, M., Herron, J., Boyer, B., 2007. The Center for Alaska Native Health Research study: a community-based participatory research study of obesity and chronic disease-related protective and risk factors. Int. J. Circumpolar Health 66, $8-18$.

Murphy, N.J., Schraer, C.D., Thiele, M.C., Boyko, E.J., Bulkow, L.R., Doty, B.J., Lanier, A.P., 1995. Dietary change and obesity associated with glucose intolerance in Alaska natives. J. Am. Diet. Assoc. 95, 676-682.

Neufingerl, N., Otten-Hofman, A., Nurdiani, R., Garczarek, U., Muhardi, L., Eussen, S., Alles, M., Sulaeman, A., Eilander, A., 2016. Generating fatty acid and vitamin D composition data of Indonesian foods. J. Food Compos. Anal. 50, 36-48.

Nobmann, E.D., Ponce, R., Mattil, C., Devereux, R., Dyke, B., Ebbesson, S.O., 2005. Dietary intakes vary with age among Eskimo adults of Northwest Alaska in the GOCADAN study, 2000-2003. J. Nutr. 135, 856-862.

Norman, A.W., 2008. From vitamin D to hormone D: fundamentals of the vitamin D endocrine system essential for good health. Am. J. Clin. Nutr. 88, 491S-499S.

Ott, R.L., Longnecker, M.T., 2016. An Introduction to Statistical Methods and Data Analysis. Cengage Learning, Boston, MA.

Ovesen, L., Brot, C., Jakobsen, J., 2003. Food contents and biological activity of 25-hydroxyvitamin D: a vitamin D metabolite to be reckoned with? Ann. Nutr. Metab. 47, 107-113.

Patterson, K.Y., Phillips, K.M., Horst, R.L., Byrdwell, W.C., Exler, J., Lemar, L.E., Holden, J.M., 2010. Vitamin D content and variability in fluid milks from a US Department of Agriculture nationwide sampling to update values in the national nutrient database for standard reference. J. Dairy Sci. 93, 5082-5090.

Pedro, S., Boba, C., Dietz, R., Sonne, C., Rosing-Asvid, A., Hansen, M., Provatas, A., McKinney, M.A., 2017. Blubber-depth distribution and bioaccumulation of PCBs and organochlorine pesticides in arctic-invading killer whales. Sci. Total Environ. 601602, 237-246.

Pehrsson, P.R., Holden, J.M., Haytowitz, D.B., 2005a. Development and application of food composition information for native American populations. The 6th International Food Data Conference Retrieved December 20, 2016 from: https://www.ars.usda. gov/research/publications/publication/?seqNo115=186478.

Pehrsson P.R., Johnson J., Nobmann E.D., Amy L., Haytowitz D.B. and Holden J., Sampling and analysis of Alaska Native subsistence foods, San Diego, CA, April 2-6, 2005, Presented at Experimental Biology 2005, 2005b, Retrieved October 13, 2017 from: https://www.ars.usda.gov/ARSUserFiles/80400525/Articles/EB05_ AlaskaFoods.pdf.

Perry, C.R., Becker, D.G., Bellow, M.E., Gregory, L.G., Pehrsson, P.R., 2002. Alaska native and American Indian sampling frame construction and sample design for the National Food and Nutrient Analysis program. 2001 Proceedings of the American Statistical Association, Section on Survey Research Methods [CD-ROM].

Phillips, K.M., Rasor, A.S., 2016. A mixed mushroom control material to facilitate interlaboratory harmonization of mushroom composition analyses. J. Food Compos. Anal. 48, 48-66.

Phillips, K.M., Patterson, K.Y., Rasor, A.R., Exler, J., Haytowitz, D.B., Holden, J.M., Pehrsson, P.R, 2006. The role of quality control and reference materials in the National Food and Nutrient Analysis program. Anal. Bioanal. Chem. 384, 1341-1355.

Phillips, K.M., Byrdwell, W.C., Exler, J., Harnly, J., Holden, J.M., Holick, M.F., Hollis, B.W., Horst, R.L., Lemar, L.E., Patterson, K.Y., Tarrago-Trani, M.T., Wolf, W.R., 2008. Development and validation of control materials for the measurement of vitamin D3 in selected U.S. foods. J. Food Compos. Anal. 21, 527-534.

Phillips, K.M., Ruggio, D.M., Horst, R.L., Minor, B., Simon, R.R., Feeney, M.J., Byrdwell, W.C., Haytowitz, D.B., 2011. Vitamin D and sterol composition of 10 types of mushrooms from retail suppliers in the United States. J. Agric. Food. Chem. 59, $7841-7853$.

Pierens, S., Fraser, D., 2015. The origin and metabolism of vitamin D in rainbow trout. J. Steroid Biochem. Mol. Biol. 145, 58-64.

Pludowski, P., Holick, M.F., Pilz, S., Wagner, C.L., Hollis, B.W., Grant, W.B., Shoenfeld, Y., Lerchbaum, E., Llewellyn, D.J., Kienreich, K., Soni, M., 2013. Vitamin D effects on musculoskeletal health, immunity, autoimmunity, cardiovascular disease, cancer, fertility, pregnancy, dementia and mortality—a review of recent evidence. Autoimmun. Rev. 12, 976-989.

Rao, D.S., Raghuramulu, N., 1996. Food chain as origin of vitamin D in fish. Comp. Biochem. Physiol. Part A: Physiol. 114, 15-19.

Reiner, J.L., Becker, P.R., Gribble, M.O., Lynch, J.M., Moors, A.J., Ness, J., Peterson, D., Pugh, R.S., Ragland, T., Rimmer, C., Rhoderick, J., Schantz, M.M., Trevillian, J., Kucklick, J.R., 2016. Organohalogen contaminants and vitamins in northern fur seals (Callorhinus ursinus) collected during subsistence hunts in Alaska. Arch. Environ. Contam. Toxicol. 70, 96-105.

Roseland, J.M., Patterson, K.Y., Andrews, K.W., Phillips, K.M., Phillips, M.M., Pehrsson, P.R., Dufresne, G.L., Jakobsen, J., Gusev, P.A., Sushma, S., Nguyen, Q.V., Makowski, A.J., Scheuerell, C.R., Larouche, G.P., Wise, S.A., Harnly, J.M., Williams, J.R., Betz, J.M., Taylor, C.L., 2016. Interlaboratory trial for measurement -of vitamin D and 25hydroxyvitamin D [25(OH)D] in foods and a dietary supplement using liquid chromatography-mass spectrometry. J. Agric. Food. Chem. 64, 3167-3175.

Roseland, J.M., Phillips, K.M., Patterson, K.Y., Pehrsson, P.R., Taylor, C.L., 2018. Vitamin D in foods: an evolution of knowledge. In: 4th ed. In: Feldman, D., Pike, J.W., Bouillon, R., Giovannucci, E., Goltzman, D., Hewison, M. (Eds.), Vitamin D: Health, Disease and Therapeutics, vol. 2. Elsevier, Cambridge, MA, USA, pp. 41-77.

Ross, C.A., Taylor, C.L., Yaktine, A.L., Del Valle, H.B. (Eds.), 2011. Dietary Reference Intakes for Calcium and Vitamin D. National Academies Press, Washington, DC, USA Retrieved March 10, 2017 from: https://www.ncbi.nlm.nih.gov/books/NBK56070/ pdf/Bookshelf_NBK56070.pdf.

Routti, H., Jenssen, B.M., Lydersen, C., Bäckman, C., Arukwe, A., Nyman, M., Kovacs, K.M., Gabrielsen, G.W., 2010. Hormone, vitamin and contaminant status during the moulting/fasting period in ringed seals (Pusa [Phoca] hispida) from Svalbard. Comp. Biochem. Physiol. 155 (Part A), 70-76.

Ryman, T.K., Boyer, B.B., Hopkins, S., Philip, J., Beresford, S.A.A., Thompson, B., Heagerty, P.J., Pomeroy, J.J., Thummel, K.E., Austin, M.A., 2015. Associations between diet and cardiometabolic risk among Yup'ik Alaska native people using food frequency questionnaire dietary patterns. Nutr. Metab. Cardiovasc. Diseases 25, 1140-1145.

Schmid, A., Walther, B., 2013. Natural vitamin D content in animal products. Adv. Nutr. Int. Rev. J. 4, 453-462.

Sharma, S., Barr, A.B., Macdonald, H.M., Sheehy, T., Novotny, R., Corriveau, A., 2011 Vitamin D deficiency and disease risk among aboriginal Arctic populations. Nutr. Rev. 69, 468-478.

Sheehy, T., Roache, C., Sharma, S., 2013. Eating habits of a population undergoing a rapid dietary transition: portion sizes of traditional and non-traditional foods and beverages consumed by Inuit adults in Nunavut, Canada. Nutr. J. 12, 70. Retrieved October 13, 2017 from: https://www.ncbi.nlm.nih.gov/pmc/articles/PMC3674896/ pdf/1475-2891-12-70.pdf.

Sheehy, T., Kolahdooz, F., Schaefer, S.E., Douglas, D.N., Corriveau, A., Sharma, S., 2014 Traditional food patterns are associated with better diet quality and improved dietary adequacy in Aboriginal peoples in the Northwest Territories, Canada. J. Hum. Nutr. Dietetics 28, 262-271.

Singleton, R., Lescher, R., Gessner, B.D., Holman, R.C., Haberling, D., Bruce, M., Bartholomew, M., Tiesinga, J., 2015. Rickets and vitamin D deficiency in Alaska native children. J. Pediatric Endocrinol. Metab. 28, 815-823.

Standlee-Strom, R.E., 2016. Qualitative Analysis of in-Depth Interviews with Nutrition Educators Identifies Challenges and Strategies for Serving Alaskan Native Clients, M.S. Thesis. Retrieved October 13, 2017 from:. University of Alaska, Fairbanks. http://hdl.handle.net/11122/6855.

Taylor, C.L., Roseland, J.M., Coates, P.M., Pehrsson, P.R., 2016. The emerging issue of 25hydroxyvitamin D in foods. J. Nutr. 64, 3167-3175.

U.S. Department of Agriculture, Agricultural Research Service, Food Surveys Research Group, 2017. What We Eat in America. Retrieved July 27, 2017 from: https://www. ars.usda.gov/northeast-area/beltsville-md/beltsville-human-nutrition-researchcenter/food-surveys-research-group/docs/wweianhanes-overview/. .

U.S. Department of Agriculture, Agricultural Research Service, 2006. USDA National Nutrient Database for Standard Reference.

U.S. Department of Agriculture, Agricultural Research Service, 2016. USDA National Nutrient Database for Standard Reference. Retrieved March 5, 2017 from:. http:// www.nal.usda.gov/fnic/foodcomp/search/.

U.S. Food and Drug Administration, 2012. Reference amounts customarily consumed per eating occasion. Code of Federal Regulations, 9CFR317.312. U.S Government Publishing Office, Washington, DC, USA Retrieved October 10, 2017 from: https:// www.gpo.gov/fdsys/granule/CFR-2012-title9-vol2/CFR-2012-title9-vol2-part317.

U.S. Food and Drug Administration, 2017. Reference Amounts Customarily Consumed per Eating Occasion. Code of Federal Regulations, 21CFR101.12. U.S. Government Publishing Office, Washington, DC, USA Retrieved October 10, 2017 from: https:// www.gpo.gov/fdsys/granule/CFR-2012-title9-vol2/CFR-2012-title9-vol2-part317.

Wacker, M., Holick, M.F., 2015. Vitamin D-effects on skeletal and extraskeletal health and the need for supplementation. Nutrients 5, 111-148.

Webb, A.R., Kline, L., Holick, M.F., 1988. Influence of season and latitude on the cutaneous synthesis of vitamin $\mathrm{D}_{3}$ : exposure to winter sunlight in Boston and Edmonton will not promote vitamin $\mathrm{D}_{3}$ synthesis in human skin. J. Clin. Endocrinol. Metab. 67, 373-378.

Weiler, H.A., Leslie, W.D., Krahn, J., Steiman, P.W., Metge, C.J., 2007. Canadian Aboriginal women have a higher prevalence of vitamin D deficiency than nonAboriginal women despite similar dietary vitamin D intakes. J. Nutr. 137, 461-465.

Wilske, J., Arnbom, T., 1996. Seasonal variation in vitamin D metabolites in southern elephant seal (Mirounga leonina) females at south Georgia. Comp. Biochem. Physiol. 114A, 9-14. 